\title{
Early Devonian miospores and organic geochemistry from the Alto Garças Sub-basin (Paraná Basin), Brazil: Biostratigraphic, paleogeographical and paleoenvironmental implications
}

\author{
Victoria J. García Muro a,*, Claudia V. Rubinstein ${ }^{a}$, Egberto Pereira ${ }^{\text {b }}$, Sérgio Bergamaschi ${ }^{\text {b }}$, \\ Paula Mendlowicz Mauller ${ }^{c}$, Philippe Steemans ${ }^{\mathrm{d}}$ \\ a Instituto Argentino de Nivología, Glaciología y Ciencias Ambientales (IANIGLA), CCT CONICET Mendoza, A. Ruiz Leal s/n, Parque General San Martín, M5502IRA Mendoza, Argentina \\ b Departamento de Estratigrafia e Paleontologia, FGEL, Universidade do Estado do Rio de Janeiro (UERJ), Rua São Francisco Xavier 524, Bloco A, $20559-900$ Rio de Janeiro, RJ, Brazil

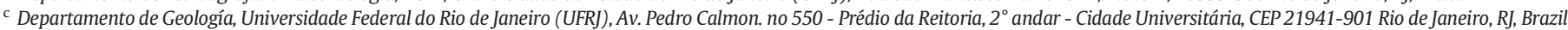 \\ d EDDY Lab/Palynology, 14 Allée du 6 Août, Bât. B-18, University of Liège, B-4000 Liège 1, Belgium
}

\section{A R T I C L E I N F O}

\section{Article history:}

Received 23 August 2019

Received in revised form 29 October 2019

Accepted 7 December 2019

Available online 12 December 2019

\section{Keywords:}

Early Devonian

Miospores

Brazil

Biostratigraphy

Paleobiogeography

Geochemistry

\begin{abstract}
A B S T R A C T
The present study concerns the palynology (mainly miospores), and geochemistry of the Jaciara section, situated $5 \mathrm{~km}$ from the town of Jaciara, Mato Grosso, in the Paraná Basin of Brazil. The age of this outcrop is considered to be Early Devonian. A study of the whole assemblage has highlighted a diversified association of miospores. Their distribution throughout the samples is somewhat erratic, which sometimes complicates the determination of the biostratigraphic attribution. However the following markers have been identified: Apiculiretusispora brandtii, Brochotriletes bellatulus, Cymbohilates baqaensis, Cymbosporites asymmetricus, Cymbosporites wellmanii, Devonomonoletes sp. 1 in Breuer and Steemans (2013), Dibolispotites sp. 2 in Breuer and Steemans (2013), Dictyotriletes subgranifer, Distaverrucosisporites steemansii, Latosporites ovalis, Scylaspora costulosa, Verrucosisporites nafudensis, Verrucosisporites onustus, Verruciosisporites stictus, Zonotriletes brevivelatus, and Zonotriletes simplicissimus. The finding of these miospores allowed recognition of the following biozones established in Saudi Arabia: the papillensis-baqaenisis Biozone, Pragian in age; the ovalis-biornatus Biozone (ovalis, milleri, asymmetricus subzones), late Pragian to early Emsian in age; and possibly the lindlarensis-sextantii Biozone, middle Emsian in age.

The presence of many taxa in common with other Gondwanan basins, particularly those from Saudi Arabia, North Africa and South America, corroborates the paleogeographical relationship between different regions of Gondwana, even between those located in very different paleolatitudes.

New geochemical analyses were also performed and add more information toward the understanding of the local paleoenvironmental evolution.
\end{abstract}

(c) 2019 Elsevier B.V. All rights reserved.

\section{Introduction}

Several miospore studies from the Lower Devonian of Brazil have been carried out over the last 30 years. These studies focus mainly on miospores from the Paraná Basin (e.g., Dino and Rodrigues, 1995; Gerrienne et al., 2001; Mendlowicz Mauller et al., 2007, 2009) and also from the Solimões Basin (Rubinstein et al., 2005), Parnaíba Basin (i.e., Grahn et al., 2005) and the Amazon Basin (Steemans et al., 2008). However, only few of these studies display the whole assemblages.

The Paraná Basin is a Western Gondwana intracratonic basin approximately $1,700,000 \mathrm{~km}^{2}$ in area located on the South American Platform (Guerra-Sommer et al., 2008; Holz et al., 2010; Souza and Marques

\footnotetext{
* Corresponding author.

E-mail address: vgarcia@mendoza-conicet.gov.ar (V.J. García Muro).
}

Toigo, 2014). It includes sediments deposited from the Ordovician through Neogene, with a maximum thickness of $5000 \mathrm{~m}$ in the axial portion of the basin, and covers parts of Brazil, Paraguay, Uruguay and Argentina (Piccirillo et al., 1988). This basin is the largest Paleozoic basin of Brazil, spreading over an area of $1,400,000 \mathrm{~km}^{2}$ on the territories of eight Brazilian states.

Mendlowicz Mauller et al. (2007) published preliminary marine and terrestrial palynomorph assemblages from the Jaciara section, in the Alto Garças Sub-Basin of the Paraná Basin. These authors recorded a relatively diverse and well-preserved miospore assemblage composed mainly of trilete spores, with subordinated monolete spores and cryptospores. The accompanying organic-walled phytoplankton (acritarchs and prasinophyte algae) provided an independent age control. A late Pragian-early Emsian age was assigned to the Jaciara section, based on the palynological results. 
The present contribution provides an integrated and detailed study of miospores, facies analysis and geochemistry. It contributes to the knowledge of late Pragian to Emsian miospores, which have been poorly studied in Brazil up to now, by better constraining the age of the Ponta Grossa Formation, by correlating with spore assemblages from other Gondwanan basins and by accurately assessing the local paleoenvironmental evolution.

\section{Geologic setting}

The Paraná Basin was established in the Late Ordovician/Early Silurian over the continental crust of the Gondwana Supercontinent, driven by thermal subsidence mechanisms which led the sedimentary deposition until the Jurassic-Cretaceous boundary.

In the Brazilian area, the pre-Carboniferous strata of the Paraná Basin can be individualized into two distinct sub-basins: the Alto Garças
Sub-basin in the north and the Apucarana Sub-basin in the south (Ramos, 1970; Melo, 1988; Pereira et al., 1998; Pereira et al., 2012; Grahn et al., 2013). A new compartment of the Paraná Basin, East Paraguay Sub-basin, was informaly proposed by Grahn et al. (2000), based on the sedimentological and biostratigraphical aspects of the pre-Carboniferous sediments in Paraguay (Fig. 1). The three subbasins had different sedimentological histories during most of this time interval. After the early Givetian, the three marine sub-basins communicated (Melo, 1988). However, no consensus has been reached regarding the subdivision of the Paraná Basin during the Silurian and Devonian times. Some authors (Milani et al., 1998, 2006, 2007) have considered that the different preservation of Devonian records in the northern and southern parts is a product of the erosion beneath the sub-Pennsylvanian unconformity (Sedorko et al., 2018). In this regard, Grahn et al. (2013) argued that the Alto Garças Sub-basin in the northern part of the Paraná Basin evolved differently from the Apucarana

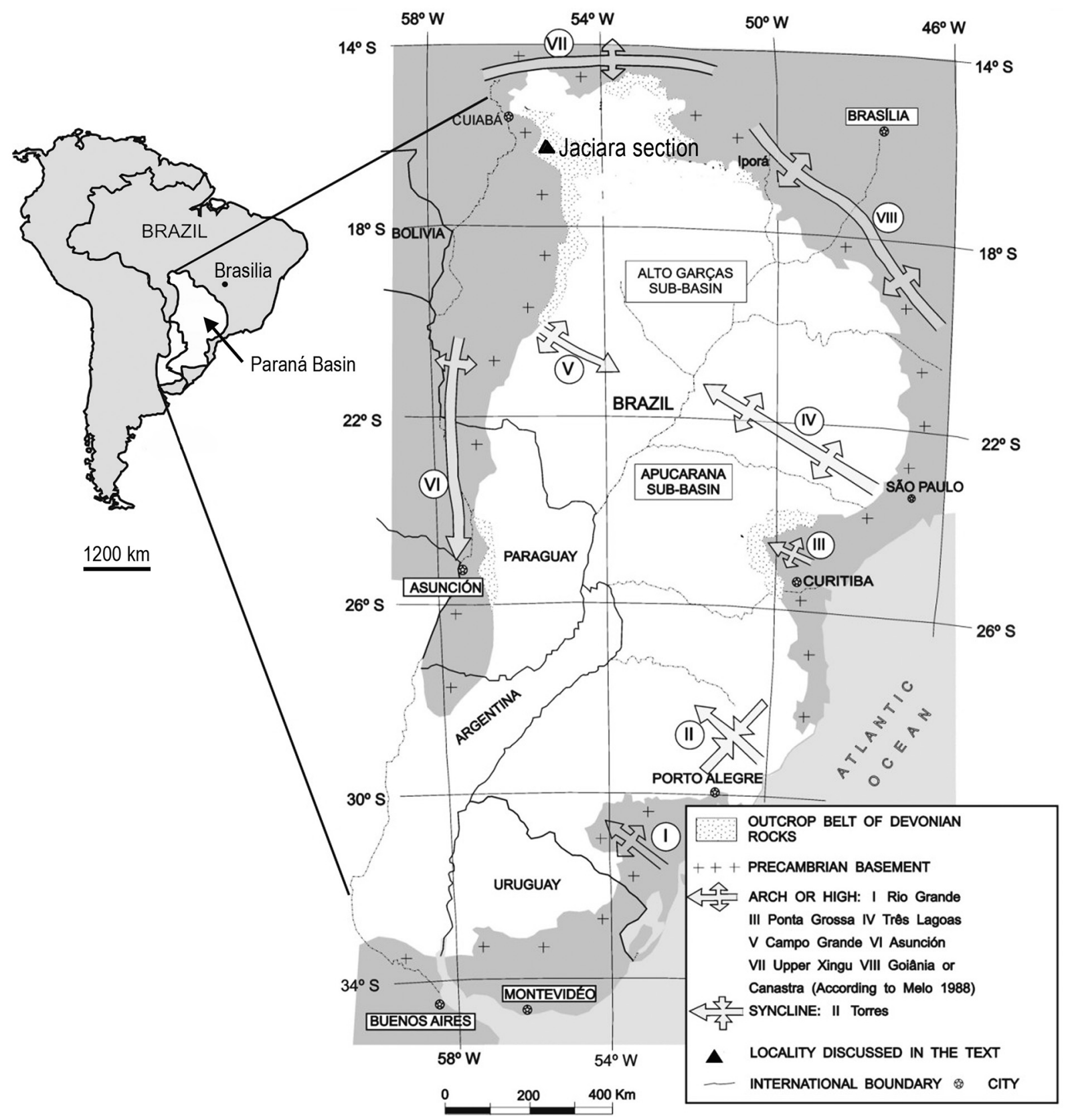

Fig. 1. Geographic map of the Jaciara section. Based on Grahn et al. (2010b). 
Sub-basin in the south, as they observed a shallower marine environment in the Alto Garças Sub-basin, which presents proportionately siltier and more arenaeceous rocks.

The Devonian rocks are exposed in narrow belts on the northnorthwestern and northeastern margins of the Alto Garças Sub-basin and are grouped in the Chapada Group named by Evans (1894). Melo (1988) re-validated these stratigraphic frameworks and proposed an informal subdivision of the Chapada Group into units 1-4, corresponding to the units described by Andrade and Camarço $(1980,1982)$. In this work, we partially follow the stratigraphic scheme proposed by Andrade and Camarço (1980). These authors subdivided the Chapada Group into a sandy basal unit named the Furnas Formation, which is overlain by transgressive fine sediments associated with the Ponta Grossa Formation. The upper unit was informally subdivided into lower, middle and upper members. However, the boundaries between the three members along the sub-basin remain controversial. Therefore, the term Ponta Grossa Formation is commonly used to include all the Devonian rocks deposited over the Furnas Formation.

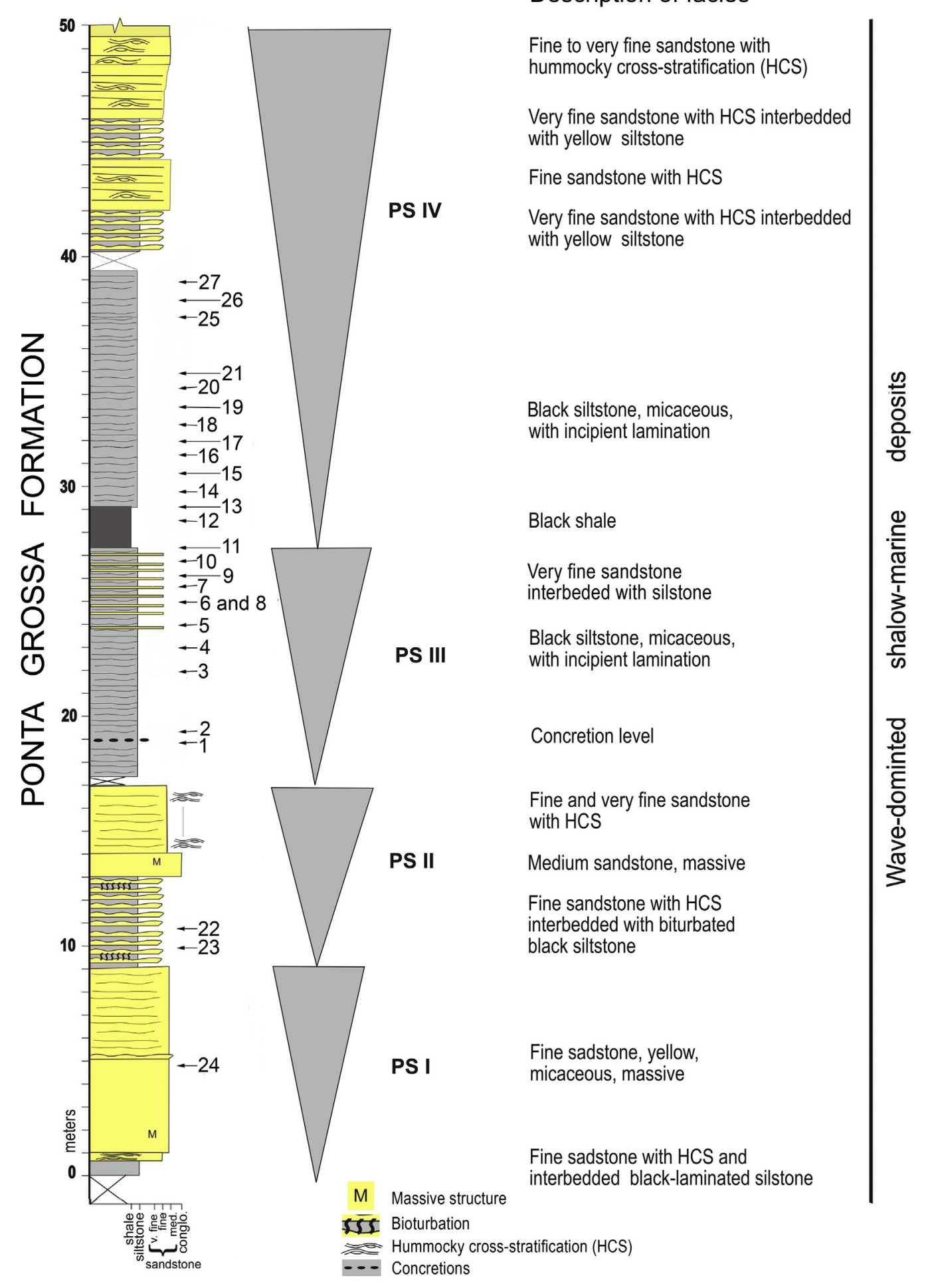

Fig. 2. Sedimentological section based on Mendlowicz Mauller et al. (2007). 


\section{Jaciara section}

The Jaciara section shows basically three facies associations: weak to moderate bioturbated siltstones with wavy-lined stratification; laminated black shales and siltstones, rarely bioturbated; and medium to fine-grained sandstones with wave-cross stratification. The facies are organized in metric coarsening - upwards cycles (Fig. 2). These cycles were deposited under shallow platform conditions, in a progressive flooding model. The facies association frequently comprises a succession of tabular bodies of decametric thickness consisting of fine/very fine-grained sandstone, which alternates with pelitic beds of similar thickness. Internally, the sandy strata exhibit small-size crosslamination, parallel plain lamination or, most often, hummocky crossstratification. Four coarsening upward cycles (PSI, PSII, PSIII and PSIV) can be observed in the section, limited by flooding surfaces (the progradational parasequence set of Van Wagoner et al., 1990). At the lower part of PSIII a concretion level indicates the beginning of the flooding in the section, when the environmental conditions become more dysoxic. In the Posamentier and James (1993) context, the parasequence stratigraphy is marked by the record of shallowingupward successions limited by abrupt increments of water depth.

The cycles described in the Jaciara section are included in the thirdorder depositional sequences. Bergamaschi and Pereira (2001), based on the sequence stratigraphy approach, subdivided the SilurianDevonian record of the Apucarana Sub-basin, in six third-order depositional sequences: Seq. A (Pridolian to Early Lochkovian in age), Seq. B (Late Lochkovian to Emsian), Seq. C (Late Emsian to Early Eifelian), Seq. D. (Eifelian), Seq. E (Late Eifelian to Late Givetian), and Seq. F (Frasnian). This stratigraphic approach was recognized by Pereira et al. (2010b) in the Alto Garças Sub-basin using the $\delta^{13} C_{\text {organic }}$ isotope signature and the Total Organic Carbon content (TOC) to characterize the flooding surfaces (FS) of each sequence defined to the Devonian section.

In a high-resolution study of a chronostratigraphic section sited in the Rio Verde de Mato Grosso (RVMT) toward the southwest from Jaciara section, Pereira et al. (2007) described fourth-order depositional cycles using an interdisciplinary approach involving geochemistry data and Ichnofossil record. The cycles described at RVMT show the same arrangement observed in the Jaciara section. In RVMT the increment of the deep conditions is signed by the increment of the TOC content, and a decrease of the bioturbation index.

\section{Materials and methods}

The material studied came from an outcrop situated $5 \mathrm{~km}$ from the town of Jaciara, Mato Grosso, Brazil ( $15^{\circ} 58^{\prime}$ 37,6" S; $55^{\circ} 00^{\prime} 31,9^{\prime \prime} \mathrm{W}$ ). A total of 27 samples were collected from the section (Fig. 2) and processed at the University of Liège, EDDy (Evolution \& Diversity Dynamics) Lab/palynology laboratory, Belgium (Table 1), using standard HCl-HF$\mathrm{HCl}$ acid maceration techniques (Traverse, 2007). The residues were oxidized with a Schulze solution $\left(\mathrm{HNO}_{3}+\mathrm{KClO}_{3}\right)$ and then screened on a $12 \mu \mathrm{m}$ sieve. The palynological slides are housed in the EDDy Lab/ Palynology.

The total organic carbon (TOC) of the samples was obtained using Leco SC-632 equipment and reported as the relative weight (\%) of the original sample. The stable carbon isotopes of the organic matter were determined with a Thermo Delta V Advantage mass spectrometer, and the results were directly expressed in the notation $\delta^{13} \mathrm{C}(\mathrm{PDB})(\%)$ $(\mathrm{PDB}=$ Belemnite from the Peedee Formation, Upper Cretaceous, South Carolina, USA). The Rock-Eval pyrolysis analyses were performed in a Vinci Technologies pyrolizer, according to the procedures of Espitalié et al. (1977). The S2 (hydrocarbon generating potential of the organic matter present in the rock, in $\mathrm{mg} \mathrm{HC} / \mathrm{g}$ rock) and Tmax (maximum hydrocarbon generation temperature, in ${ }^{\circ} \mathrm{C}$, measured at the maximum height of the $\mathrm{S} 2$ peak) were performed, except for those samples with very low TOC content.
Table 1

Stratigraphic order of the samples from Jaciara section, Río de Janeiro (RJ). Corresponding laboratory number for the studied samples, prepared in the University of Liège (ULg), Belgium.

\begin{tabular}{ll}
\hline Stratigraphic order - sample number $(\mathrm{RJ})$ & Laboratory number $(\mathrm{ULg})$ \\
\hline 27 & 61706,61858 \\
26 & 61704,61857 \\
25 & 61702,61856 \\
21 & 61694,61852 \\
20 & 61692,61851 \\
19 & 61690,61850 \\
18 & 61688,61849 \\
17 & 61686,61848 \\
16 & 61684,61847 \\
15 & 61682,61846 \\
14 & 61680,61845 \\
13 & 61678,61844 \\
12 & 61676,61843 \\
11 & 61674,61842 \\
10 & 61671,61841 \\
9 & 61670,61840 \\
7 & 61666,61838 \\
8 & 61668,61839 \\
6 & 61664,61837 \\
5 & 61662,61836 \\
4 & 61660,61835 \\
3 & 61658,61834 \\
2 & 61655,61833 \\
1 & 61654,61832 \\
22 & 61696,61853 \\
24 & 61698,61854 \\
\hline
\end{tabular}

\section{Results}

\subsection{Palynology}

The palynological content of the Jaciara section is well-preserved and diverse, enabling the recognition of 70 miospores species.

Mendlowicz Mauller et al. (2007) recognized 39 spore species in this section, 19 of which were illustrated. Twenty-two of them were also recorded in the present study. The genera Aneurospora, Archaeozonotriletes, Chelinospora, Concentricosisporites, Cymbohilates, Distaverrusporites, Granulatisporites, Krauselisporites and Devonomonoletes are among the taxa recorded for the first time in Jaciara.

The complete list of species is given in the Appendix, and the corresponding illustrations are depicted in Plates I-V. Description and remarks are provided for unidentified spores (if necessary) or when differences with the original diagnoses of the species were observed.

The stratigraphic distribution of the miospores in the studied sections is presented in Fig. 3.

\subsection{Geochemistry}

The geochemical data are shown in Table 2 and Fig. 4. The isotopic and geochemistry data fit very well with the sedimentological arrangement. The residual values of the TOC content decrease toward the top of the section as the section becomes sandier. The aspect is well-defined by the isotopic excursion, which becomes more positive in the same direction. The pyrolysis parameters (S2, HI, Tmax) show an organic matter that is degraded, immature and a basically of Type III (Fig. 4).

\section{Discussion}

\subsection{Biostratigraphy and paleogeography}

The global stratigraphic distribution of the miospores observed in the Jaciara section (Fig. 5) suggests a late Pragian - possibly middle Emsian age. Many spores have long stratigraphic ranges (e.g., Ambitisporites avitus/dilutus, Archaeozonotriletes chulus/nanus, Dibolisporites echinaceus 

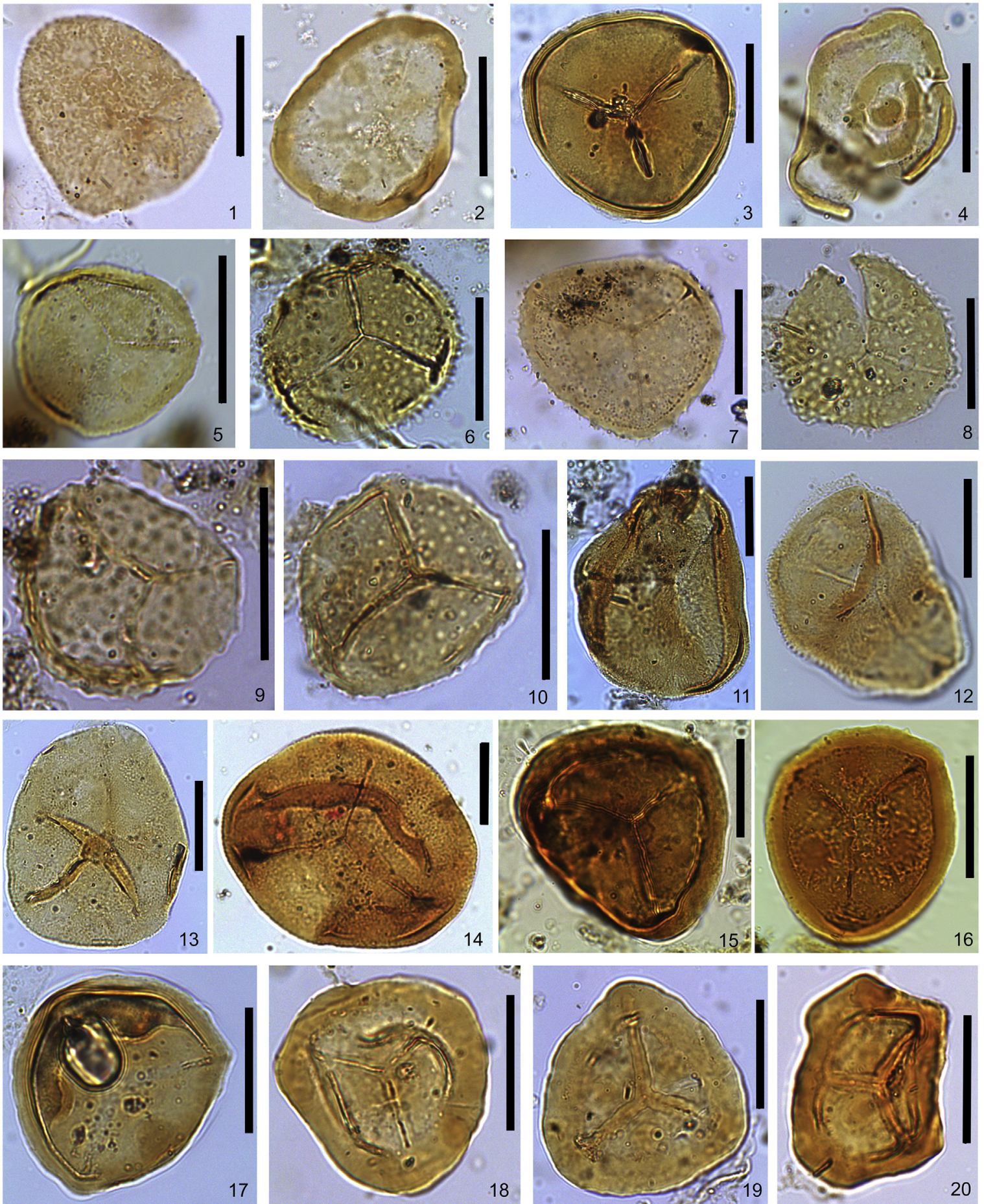

Plate I.

1. Acinosporites sp. 1, sample 5, 61836 (Q44)

2.16. Ambitisporites eslae (Cramer and Díez) Richardson et al., 2001, sample 12, 61843 (S51/3); 1, 61654 (Q39/2)

3. Ambitisporites sp., sample 10, 61671 (G43/4)

4. Amicosporites streelii Steemans, 1989, sample 14, 61680 (K38/2)

5. Aneurospora isidori (Cramer and Díez) Richardson et al., 1982, sample 1, 61654 (N40/1)

6. Aneurospora sp. 1 in Rubinstein and Steemans (2002), sample 1, 61832 (N36)

7. Aneurospora sp. 2 in Rubinstein and Steemans (2002), sample 6, 61664 (V28/2)

8. Aneurospora cf. sp. 4 in Rubinstein and Steemans (2002), sample 11, 61674 (D22)

9. 10. Aneurospora sp. 5 in Rubinstein and Steemans (2002), samples 11, 61674 (P44); 16, 61684 (U42)

11. 12. Apiculiretusispora brandtii Streel, 1964, samples 16, 61684 (E46); 5, 61836 (D45/1)

13. 14. Apiculiretusispora plicata (Allen) Streel, 1967, sample 4, 61660 (C43/3); 9, 61670 (Q45/2)

15. Archaeozonotriletes chulus (Cramer) Richardson and Lister, 1969, sample 3, 61658 (R39/4)

17. Archaezonotriletes sp. 1, samples 2, 61833 (L51)

18-20. Archaeozonotriletes sp. 2, samples 20, 61692 (V34/2); 4, $61660(\mathrm{H} 37 / 1) ; 19,61690$ (M28/4) Scale bar $=20 \mu \mathrm{m}$. 

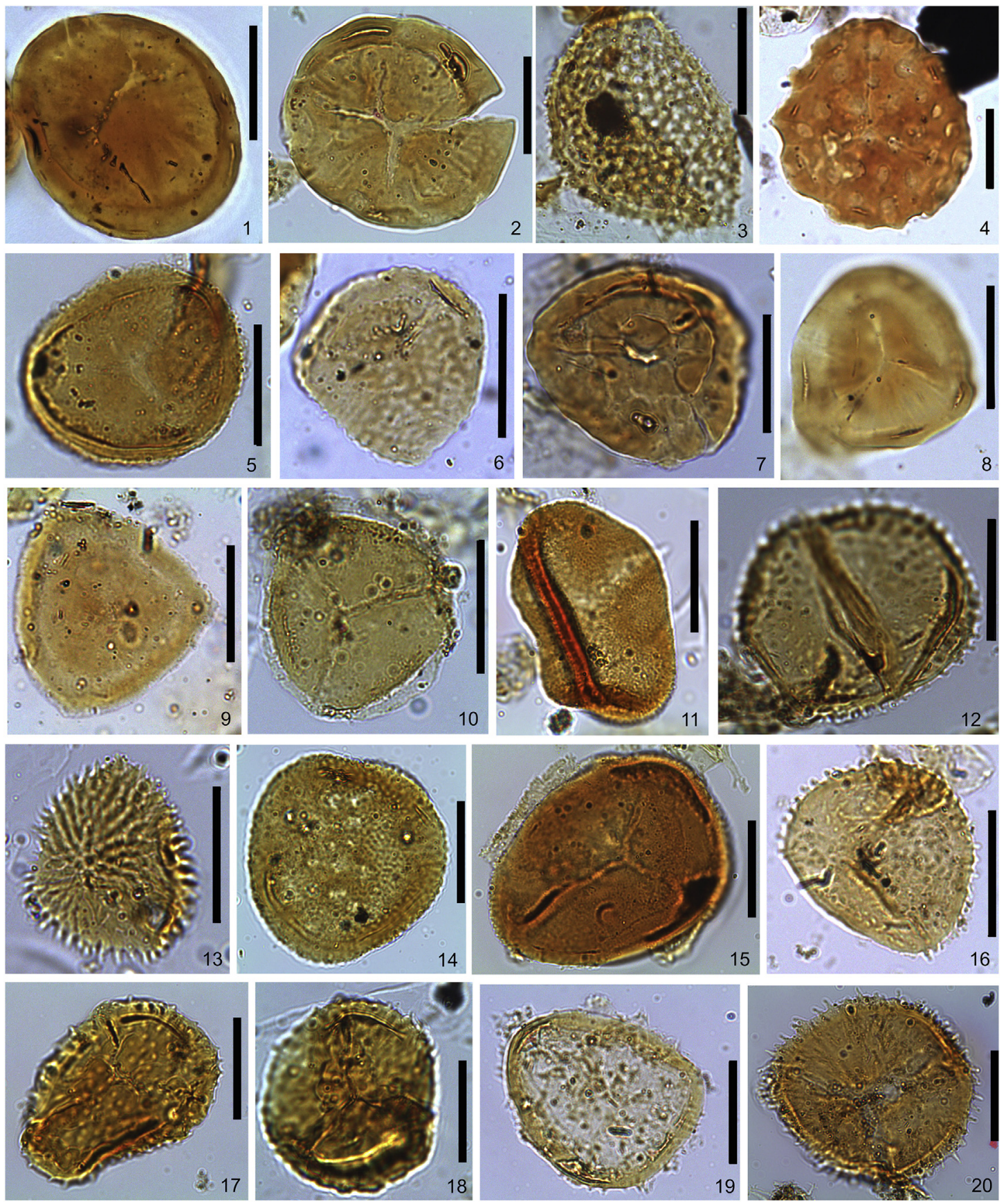

Plate II.

1. Artemopyra inconspicua Breuer et al., 2007, sample 8, 61668 (L29/1)

2. Artemopyra recticosta Breuer et al., 2007, sample 11, 61842 (C36/4)

3. Brochotriletes bellatulus Steemans, 1989, sample 2, 61655 (N44/1)

4. Brochotriletes foveolatus Naumova, 1953, sample 19, 61850 (Q31)

5. Camarozonotriletes alruwailii Breuer et al., 2015, sample 15, 61682 (W40)

6. Chelinospora cf. retorrida Turnau, 1986, sample 17, 61666 (T34/4)

7. Chelinospora verrucata var. verrucata Morphon García Muro et al. (2014), sample 5, 61836 (M36/2)

8. Concentricosisporites agradabilis (Rodriguez) Rodriguez, 1983, sample 5, 61662 (J45/4)

9. Concentricosisporites cf. sagittarius (Rodriguez) Rodriguez, 1983, sample 9, 61840 (039/4)

10. Zonotriletes cf. simplicissimus Breuer et al., 2007, sample 3, 61834 (M34/3)

11. Cymbohilates allenii var. magnus Richardson, 1996, sample 23, 61854 (J41/1)

12. Cymbohilates baqaensis Breuer et al., 2007, sample 10, 61841 (Y31)

13. Cymbohilates horridus Richardson, 1996, sample 2, 61833 (M37/2)

14. Cymbohilates sp., sample 22, 61696 (H46/4)

15. Cymbosporites asymmetricus Breuer et al., 2007, sample 5, 61836 (D42/2)

16. Cymbosporites dammamensis Steemans, 1995, sample 19, 61690 (X39/1)

17. Cymbosporites dittonensis Richardson and Lister, 1969, sample 27, 61858 (X49/1)

18. Cymbosporites echinatus Richardson and Lister, 1969, sample 3, 61658 (T46/2)

19. Cymbosporites rarispinosus Steemans, 1989, sample 11, 61674 (Y24)

20. Cymbosporites wellmanii Breuer and Steemans, 2013, sample 1, 61832 (G49)

Scale bar $=20 \mu \mathrm{m}$ 

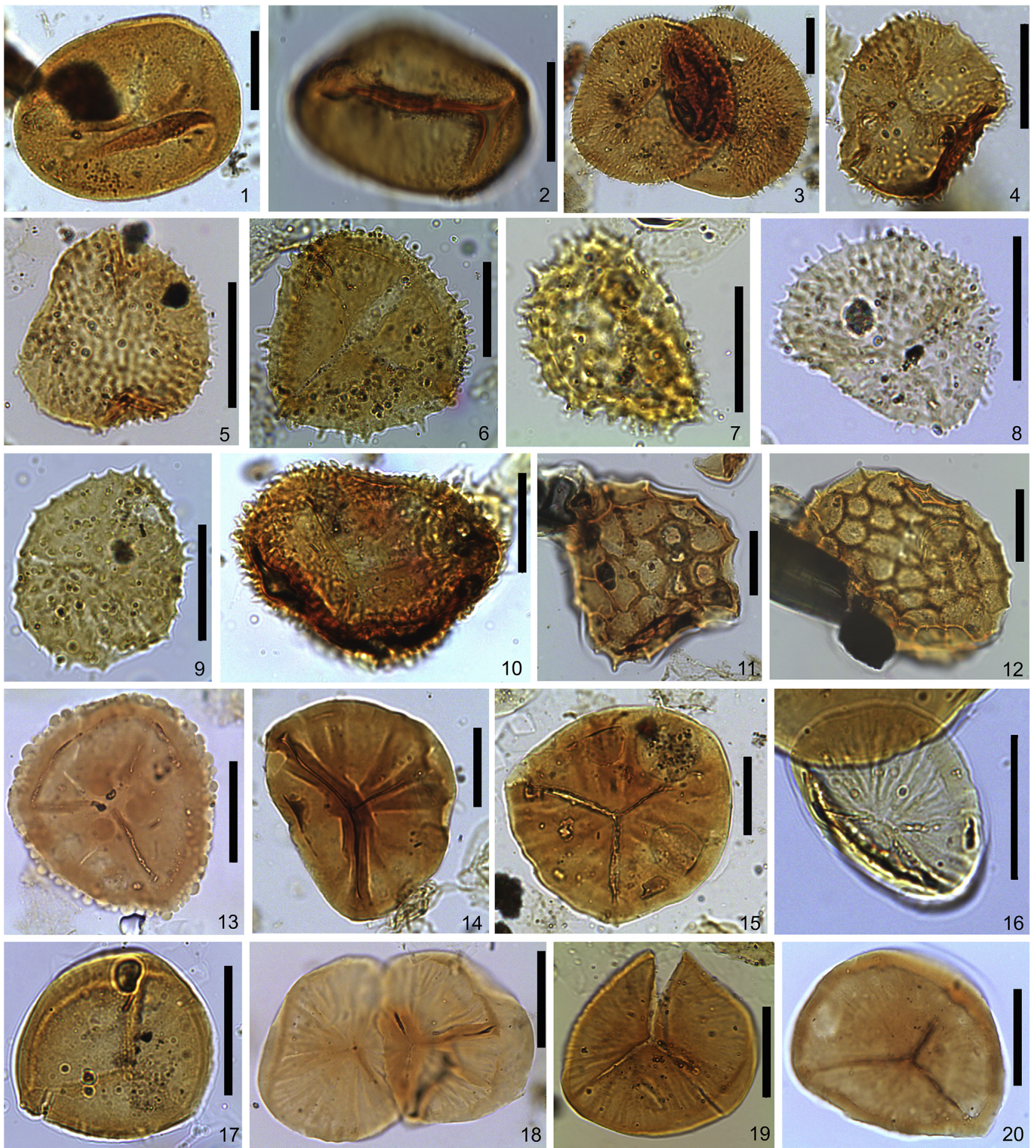

Plate III.

1. cf. Devonomonoletes sp. 1 in Breuer and Steemans (2013), sample 18, 61688 (R36/1);

2. Devonomonoletes sp. 1 in Breuer and Steemans (2013), sample 1, 61654 (R24/3)

3. 10. Dibolisporites echinaceus (Eisenack) Richardson, 1965, sample 19, 61690 (K38), sample 14, 61845 (R45/1)

4. 9. Dibolisporites eifeliensis (Lanninger) McGregor, 1973, sample 20, 61692 (Q36/1), sample 23, 61698 (U32/3)

5. Dibolisporites cf. wetteldorfensis Lanninger, 1968, sample 11, 61842 (T29/3)

6. Dibolisporites sp. 1, sample 23, 61854 (S35/3)

7. 8. Dibolisporites sp. 2 in Breuer and Steemans (2013), sample 23, 61698 (T47/2); 25, 61856 (M33/4)

11. Dictyotriletes emsiensis Morphon Rubinstein et al. (2005), sample 14, 61845 (G38/3)

12. Dictyotriletes subgranifer McGregor, 1973, sample 24, 61855 (E30/3)

13. Distaverrucosisporites steemansii Rubinstein et al., 2018, sample 4, 61835 (L41/3)

14. Emphanisporites cf. laticostatus Breuer and Steemans, 2013, sample 16, 61847 (Q41/1)

15. Emphanisporites mcgregorii Cramer, 1966, sample 7, 61666 (M28/2)

16. Emphanisporites neglectus Vigran, 1964, sample 2, 61833 (S51)

17. Emphanisporites protophanus Richardson and Ioannides, 1973, sample 1, 61832 (N48)

18. Emphanisporites rotatus (McGregor) McGregor 1973, sample 5, 61836 (H46)

19. 20. Emphanisporites? tenuis García Muro et al., 2018, sample 1, 61654 (038/4); 5, 61836 (W34/4)

Scale bar $=20 \mu \mathrm{m}$. 

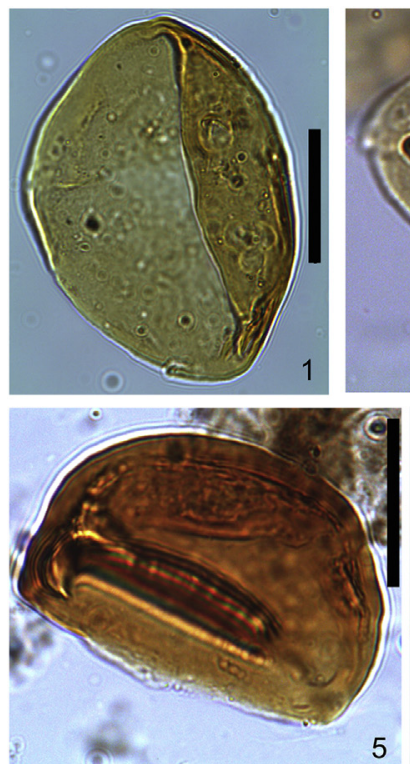

5
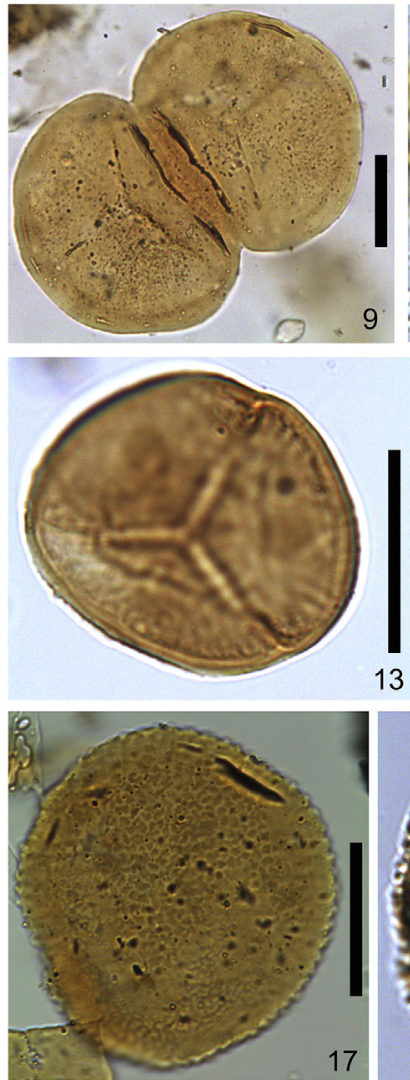
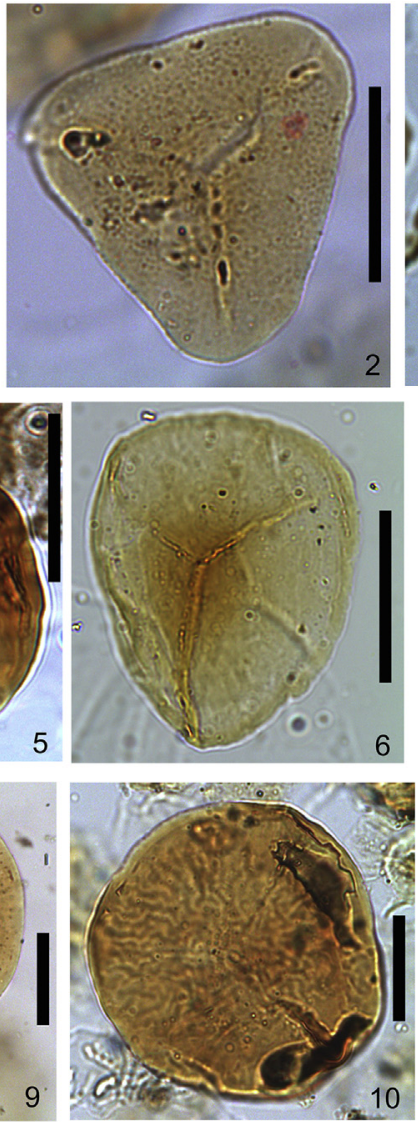

10
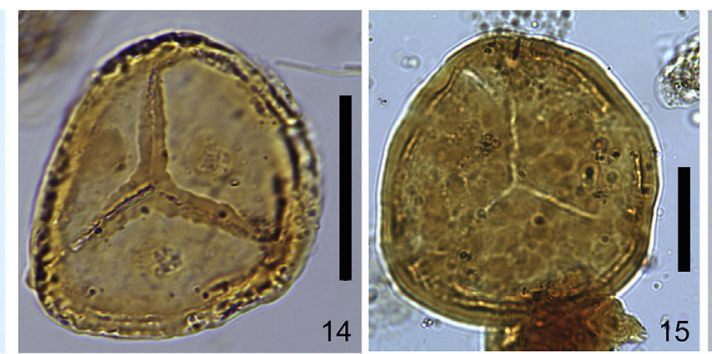

11

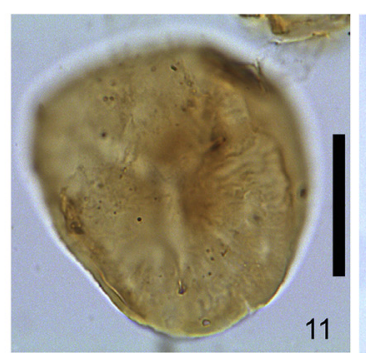

3
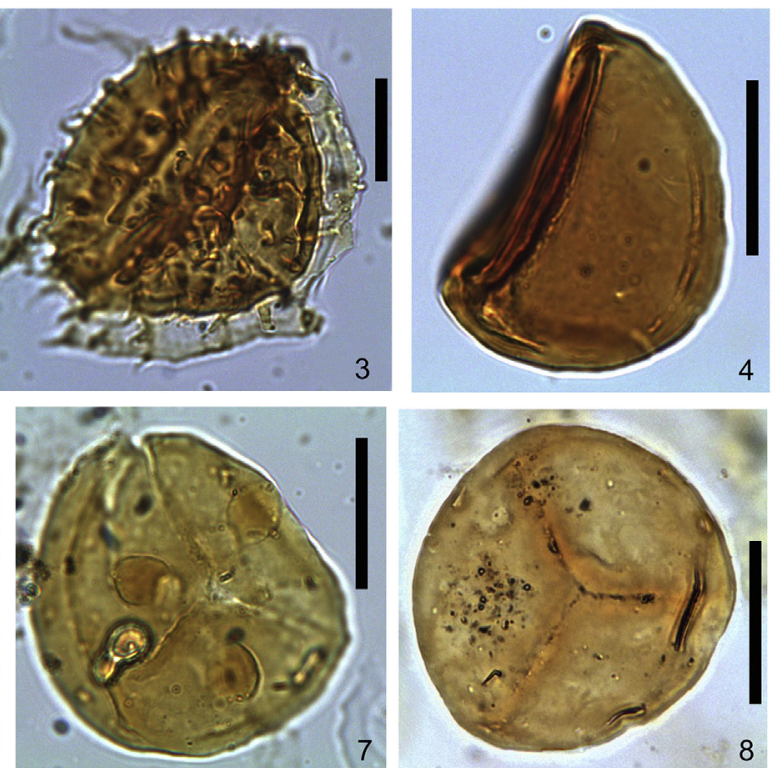

8
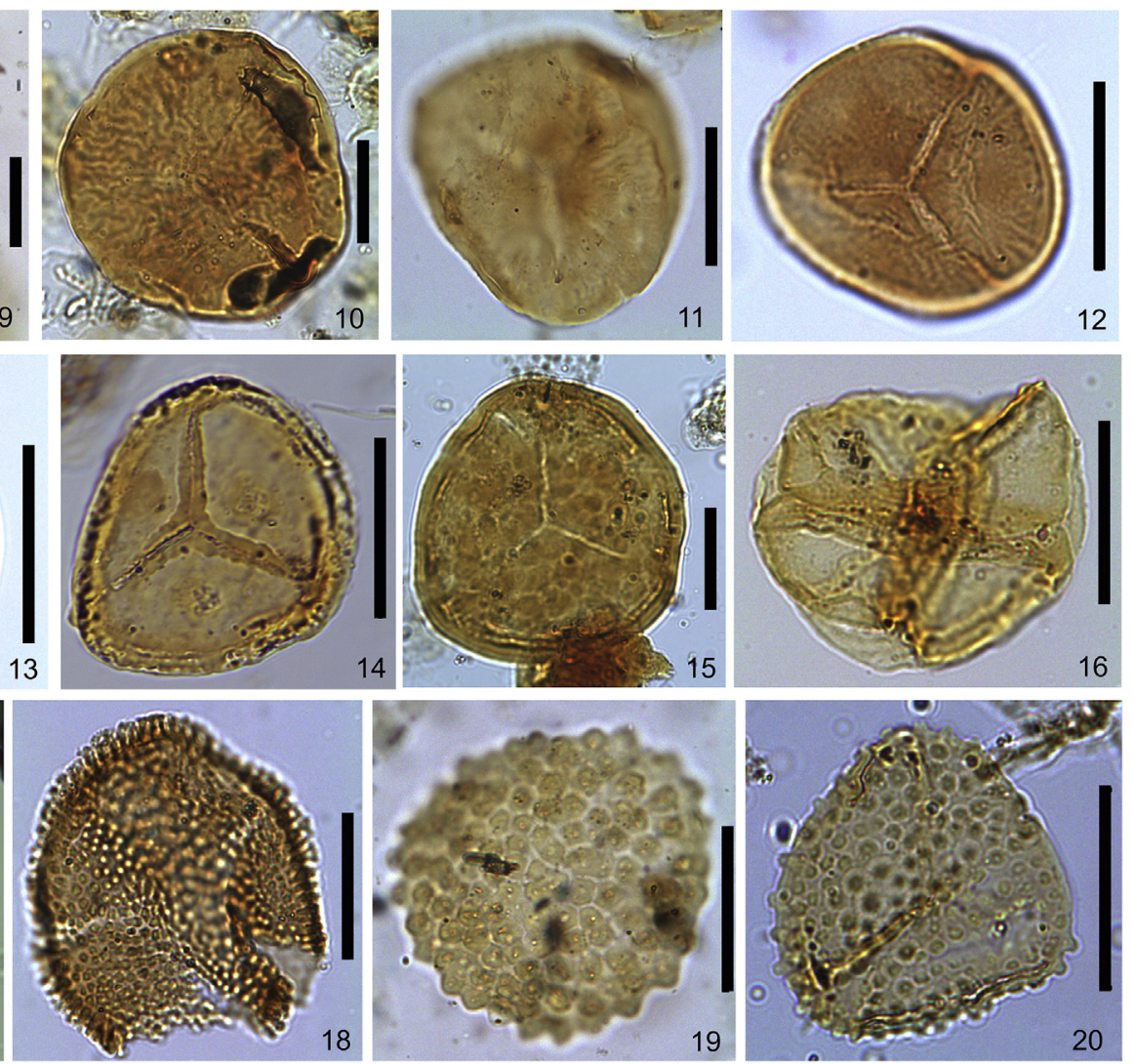

\section{Plate IV.}

1. Gneudnaspora divellomedia (Chibrikova) Balme, 1988 var. divellomedia Breuer et al., 2007, sample 1, 61832 (Y37/2)

2. Granulatisporites concavus Breuer and Steemans, 2013, sample 25, 61856 (N42)

3. Kraeuselisporites gaspesiensis McGregor, 1973, sample 10, 61841 (H28)

4. Latosporites ovalis Breuer et al., 2007, sample 15, 61846 (D42/1)

5. cf. Latosporites sp., sample 2, 61655 (M35/4)

6. Retusotriletes sp., sample 23, 61698 (H42)

7. Retusotriletes maculatus McGregor and Camfield, 1976, sample 26, 61704 (R50/1)

8. Retusotriletes triangulatus (Streel) Streel, 1967, sample 5, 61662 (L38/3)

9. Retusotriletes sp., sample 6, 61664 (Y31)

10. Scylaspora costulosa Breuer et al., 2007, sample 4, 61660 (M45/2)

11. Scylaspora costulosa Breuer et al., 2007, sample 5, 61662 (K46/1)

12. 13. Scylasporora sp. 1 , sample 15,61846 (N36/1)

14. Synorisporites papillensis Morphon Breuer and Steemans, 2013, sample 1, 61654 (H34/2)

15. Synorisporites verrucatus Richardson and Lister, 1969, sample 1, 61832 (R38/2)

16. Tetrahedraletes medinensis (Strother and Traverse) Wellman and Richardson, 1993, sample 19, 61690 (P23)

17. Verrucosisporites nafudensis Breuer and Steemans, 2013, sample 22, 61853 (K43)

18. Verrucosisporites onustus Breuer and Steemans, 2013, sample 15, 61682 (P37/3)

19. Verrucosisporites stictus Breuer and Steemans, 2013, sample 6, 61664 (D36/2)

20. Verrucosisporites sp. 1 in Breuer and Steemans (2013), sample 2, 61833 (T40/3)

Scale bar $=20 \mu \mathrm{m}$. 

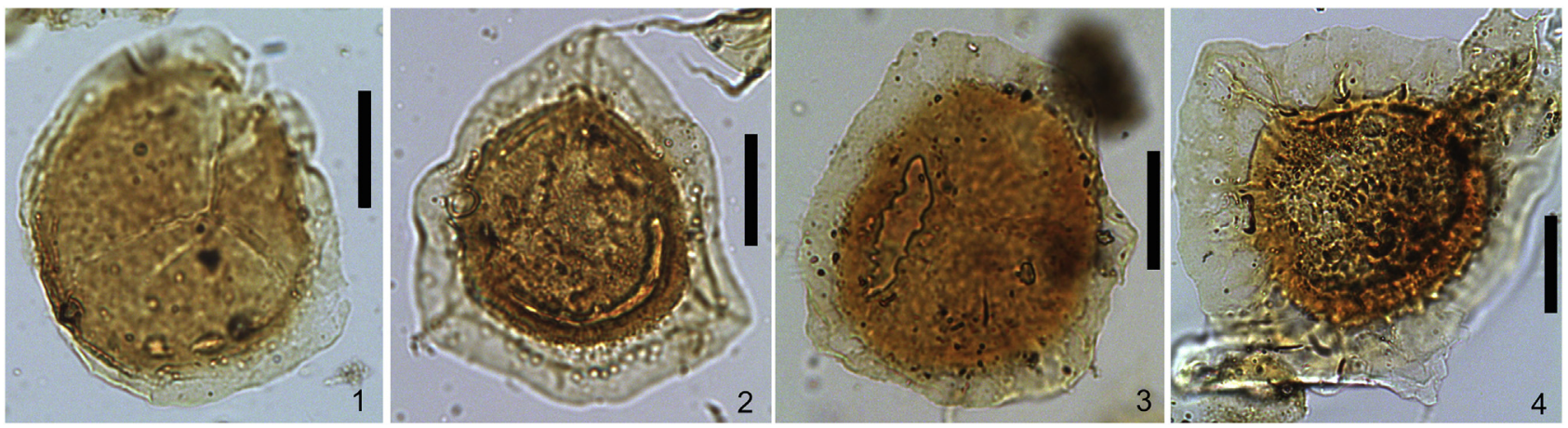

Plate V.

1. Zonotriletes brevivelatus Breuer and Steemans, 2013, sample 17, 61686 (T43/2)

2. Zonotriletes cf. simplicissimus Breuer et al., 2007, sample 10, 61671 (H26/4)

3. Zonotriletes sp. 5 in Jardiné and Yapaudjian (1968), sample 20, 61692 (L30/1)

4. Zonotriletes sp. 1, sample 5, 61836 (E34/3)

Scale bar $=20 \mu \mathrm{m}$.

and Brochotriletes foveolatus, and others which have been left in open nomenclature) and are not relevant for biostratigraphy. Nevertheless, the age of the assemblage can be constrained to the Early Devonian because of the presence of such species as Dictyotriletes emsiensis, Latosporites ovalis, Synorisporites papillensis Morphon and Dibolisporites eifeliensis that first appear in the Devonian and because of the absence of typical Middle Devonian spores.

The four lower samples $(24,23,22$ and 1$)$ contain, among others, species only known from the late Pragian up to the Emsian; these include Scylaspora costulosa, Dibolisporites sp. 2 in Breuer and Steemans, 2013 and Devonomonoletes sp. 1 in Breuer and Steemans, 2013.

Synorisporites papillensis Morphon, which includes? Knoxisporites riondae, also appears beginning in the lowermost sample (24). Even though there are some oldest occurrences, in the late Silurian to early Lochkovian (Cramer and Diéz, 1975; Rodriguez, 1978), the species mostly ranges from the Pragian up to the Eifelian (Breuer and Steemans, 2013 and references therein; Rubinstein et al., 2018). Synorisporites papillensis is one of the two spores which characterize the late Pragian papillensis-baqaensis Biozone of Saudi Arabia (Breuer and Steemans, 2013) (Fig. 5 and Fig. 6). A revision of the taxa would probably be necessary to explain this biostratigraphic discrepancy.

Dictyotriletes subgranifer, also recorded in sample 24, is a good biostratigraphic marker of the late Pragian-early Emsian Interval Biozone Su of Euramerica (Steemans, 1989). The species ranges up into the late Emsian annulatus-protea Zone (Streel et al., 2000; Breuer and Steemans, 2013). Dibolisporites sp. 2 in Breuer and Steemans (2013), that appears in sample 23, ranges from the late Pragian papillensisbaqaensis Biozone up to the early Emsian ovalis-biornatus Biozone of Saudi Arabia. Verrucosisporites nafudensis is late Pragian to early Emsian in age, also ranging from the papillensis-baqaensis to ovalis-biornatus Biozone (Breuer and Steemans, 2013).

Cymbosporites wellmanii (sample 1) is only known in the papillensisbaqaensis Biozone (Breuer and Steemans, 2013; Breuer et al., 2015), which is late Pragian in age. The first appearance of Apiculiretusispora brandtii, recorded in the same sample as $C$. wellmanii, is also around the late Pragian (Breuer and Steemans, 2013). Devonomonoletes sp. 1 in Breuer and Steemans (2013) and Scylaspora costulosa, which range from the late Pragian up to the late Emsian, also appear in sample 1, supporting the assigned age.

Even though Brochotriletes bellatulus is one of the characteristic species of the AB Biozone of Euramerica, early Emsian in age (Steemans, 1989), the presence of a single specimen in sample 2 prevents a trustable assignment of this sample to the Emsian. Verrucosisporites sp. 1 in Breuer and Steemans (2013) appears in the same sample. It ranges from the late Pragian-early Emsian ovalis-biornatus zone to the middle Emsian lindlarensis-sextantii zone of northwestern Gondwana (Breuer and Steemans, 2013). Thus, a late Pragian to early Emsian age could be assigned to this sample.

The confirmed presence of Cymbosporites asymmetricus in sample 5 would suggest an age no older than late-early Emsian for this sample (ovalis-biornatus Biozone, asymmetricus Subzone). Verrucosisporites stictus, which appears in sample 6, ranges from the late Pragian papillensis-baqaensis Biozone up to the late-early Emsian ovalisbiornatus Biozone (asymmetricus subzone). Verrucosisporites onustus, present in sample 15, ranges from the papillensis-baqaensis up to the early ovalis-biornatus Biozones (Breuer and Steemans, 2013). Latosporites ovalis and Camarozonotriletes alruwailii, appear in the same sample. Latosporites ovalis is one of the key species of the ovalisbiornatus Biozone (Breuer and Steemans, 2013), which extends from the late Pragian to the late-early Emsian, but possibly reaching the Upper Devonian (Liu et al., 2019). Camarozonotriletes alruwailii, extends in Saudi Arabia from the ovalis to the milleri sub-biozones of Breuer and Steemans (2013), but its presence in the sample 15 would indicate that it reaches the upper part of the ovalis-biornatus biozone (asymmetricus Subzone). Spores present in samples 16-21 also support the late-early Emsian age. Therefore, from sample 5 up to sample 21, that is the middle part of Jaciara section, the miospores assemblage would point to a late-early Emsian age. Actually, they correspond to the asymmetricus sub-biozone of northwestern Gondwana (Breuer and Steemans, 2013) because of the presence of the eponym species Cymbosporites asymmetricus. .

Granulatisporites concavus (sample 25) first occurs in the lindlarensis-sextantii Biozone (Breuer and Steemans, 2013), and characterizes the middle to late Emsian. Even though, key species of such biozone are absent, a younger age could be hinted.

Interestingly, in samples 11 and 27 , more than $30 \%$ of the palynomorphs are represented by leiospheres and sphaeromorph taxa. Several hypotheses have been made to explain high abundance (75-95\%) of leiospheres, such as environments with high energy (Dorning and Bell, 1987), near shore or deep environments (Molyneux et al., 1996) and lagoons or restrict and/or stress environments (Higgs and Williams, 2011). According to the sedimentological information from the Jaciara section, sample 11, and possibly sample 27, would correspond to distal environments, related to the maximum flooding surfaces observed in the section (Fig. 2).

The correlation with the biozonation established by Melo and Loboziak (2003) is not very precise. Because of the absence of Grandispora and Samarisporites species, the Jaciara section is clearly below the GS Biozone. The base of this biozone is poorly constrained and varies from approximately the late-middle up to the late Emsian, and, by comparison with European biozonation (Streel et al., 1987), it would correspond to the late Emphanisporites foveolatus- 


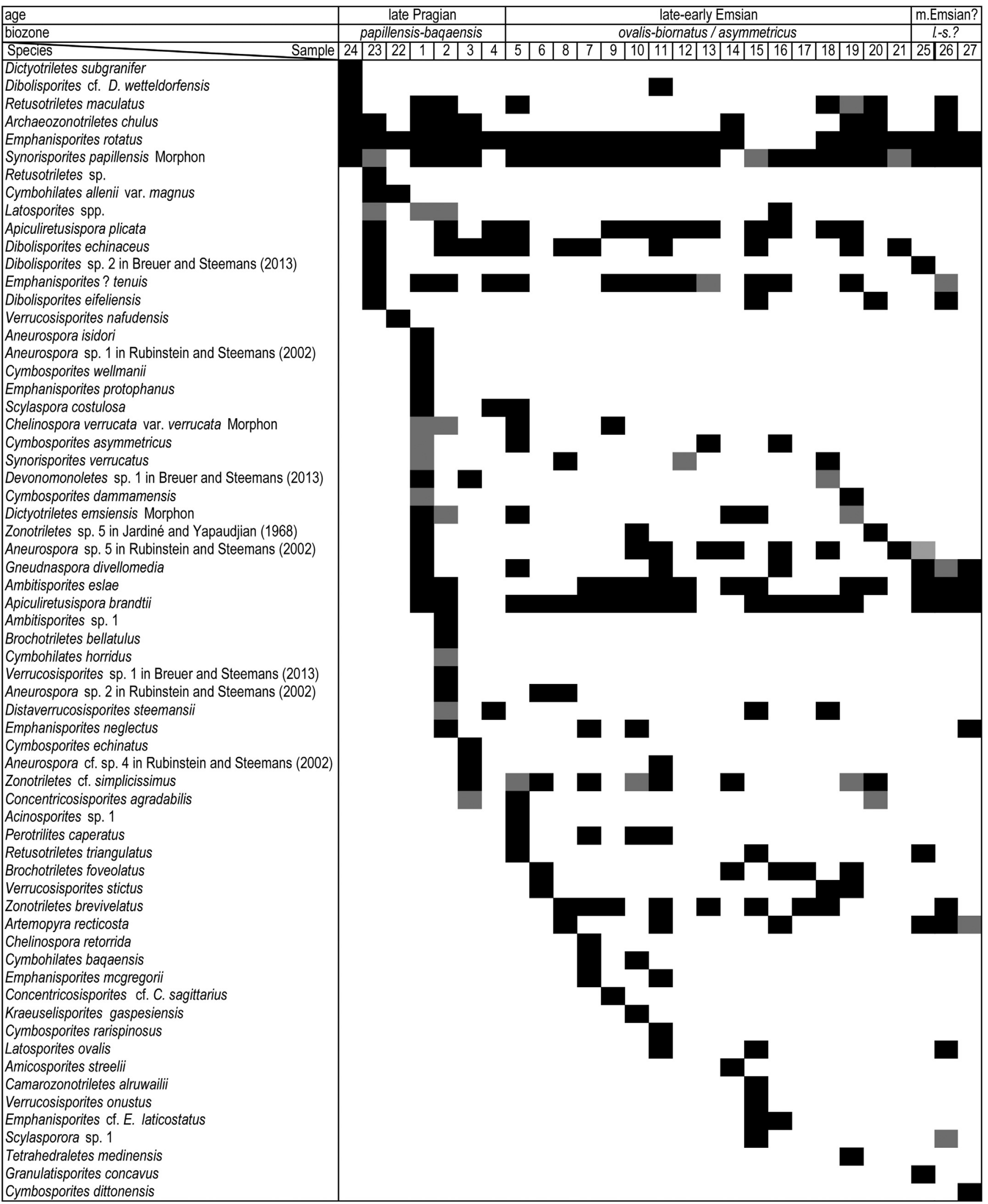

Fig. 3. Stratigraphic distribution of the miospores in the Jaciara section. The black rectangles indicate species presence; the gray rectangles are questionable occurrences. 
Table 2

Geochemical and isotopic data.

\begin{tabular}{llllll}
\hline Sample & TOC $(\%)$ & ${ }^{13}$ Corg $(\% \circ)$ & S2 $(\mathrm{mgHC} / \mathrm{g}$ rock $)$ & HI $(\mathrm{S} 2 / \mathrm{g} \mathrm{TOC})$ & $\operatorname{Tmax}\left({ }^{\circ} \mathrm{C}\right)$ \\
\hline 27 & 0,4 & $-28,32$ & 0,3 & 75 & 428 \\
26 & 0,5 & $-28,807$ & 0,42 & 84 & 428 \\
25 & 0,52 & $-28,784$ & 0,98 & 188 & 431 \\
21 & 0,72 & $-27,666$ & 0,31 & 43 & 441 \\
20 & 0,62 & $-28,755$ & 0,4 & 65 & 428 \\
19 & 0,55 & $-29,473$ & 0,37 & 67 & 430 \\
18 & 0,49 & $-28,792$ & 0,37 & 76 & 432 \\
17 & 0,57 & $-29,087$ & 0,36 & 63 & 428 \\
16 & 0,67 & $-28,955$ & 0,48 & 72 & 430 \\
15 & 0,36 & $-28,38$ & & & \\
14 & 0,27 & $-28,515$ & & 56 & 435 \\
13 & 0,48 & $-29,241$ & 0,27 & 67 & 432 \\
12 & 0,61 & $-29,205$ & 0,41 & 124 & \\
11 & 0,51 & $-29,282$ & 0,63 & & 432 \\
10 & 0,3 & $-27,315$ & & 66 & 425 \\
9 & 1 & $-26,756$ & 0,66 & 55 & 437 \\
8 & 0,55 & $-29,183$ & 0,3 & 48 & \\
7 & 0,5 & $-27,851$ & 0,24 & & \\
6 & 0,42 & $-28,661$ & & 60 & \\
5 & 0,81 & $-29,295$ & 0,49 & 989 \\
4 & 0,49 & $-29,3$ & 0,48 & & \\
3 & 0,43 & $-28,945$ & & & \\
2 & 0,29 & $-27,831$ & & & \\
1 & 0,35 & $-27,772$ & 0,23 & & \\
22 & 0,15 & $-26,951$ & & & \\
23 & 0,25 & $-27,546$ & & & \\
24 & 0,14 & $-26,244$ & & & \\
\hline
\end{tabular}

Verruciretusispora dubia (FD) and the Acinosporites apiculatusCalyptosporites proteus (AP) Biozones. The base of the Jaciara section is situated in the Dictyotriletes emsiensis (Ems) Biozone. This biozone is separated by a large hiatus with the younger GS Biozone (Melo and Loboziak, 2003). The top of the Ems Biozone is located in the early Emsian, and its base is in the latest part of the Lochkovian. However, because of progressive variations through time in the morphology of Dictyotriletes emsiensis, Rubinstein et al. (2005) created a Morphon first appearing in the early part of the Lochkovian. Therefore, the Ems Biozone could be extended downward to the Lochkovian N Interval Zone of western Europe (Rubinstein et al., 2005).

The Jaciara section may be correlated with other sections and boreholes in the Ponta Grossa Formation of the Paraná Basin that indicate the late Pragian-early Emsian age. Grahn et al. (2013) observed Apiculiretusispora brandii, Apiculiretusispora plicata, Dibolisporites echinaceus, Scylaspora costulosa and Synorisporites papillensis, among others, in the Jaguariaíva section. In the Tibagi-Telêmaco Borba section, the authors recorded cf. Cymbosporites asymmetricus, Dictyotriletes subgranifer, and cf. Artemopyra recticosta. Grahn et al. (2010b) documented Dictyotriletes subgranifer, Scylaspora costulosa, and Apiculiretusispora brandtii in the well 9-PPG-6-PR while in the Apucarana Sub-basin (Parana Basin). In addition, the well 2-CS-1-PR and the section Campus UEPG and Av. Monteiro Lobata yielded spores mostly with long stratigraphic ranges, although an Early Devonian age was interpreted (Grahn et al., 2010b). These three localities were independently dated by chitinozoans. According to the correlations done between spores and chitinozoans in Grahn et al. (2013), the Jaciara section would correspond to the upper part of the Ramochitina magnifica and the lower part of the Ancyrochitina pachycerata chitinozoan biozones, which correspond to the late Pragian-early Emsian.

The Chapada dos Guimarães area of the Parana Basin, from sample 274 to 288 , showed an assemblage similar to the Jaciara assemblage (Grahn et al., 2010a). These assemblages correspond to the the Chapada Group Unit 2 (lower part), equivalent to the Ponta Grossa Formation, and were dated as late Pragian-early Emsian (Ems Biozone from Brazil and PoW Su Biozone from Europe). The species observed in the middle and upper parts of the Jaciara section are lacking in the Chapada dos Guimarães area. This suggests the possible existence of a hiatus in the Chapada dos Guimarães area. The middle Emsian age has not been recognized thus far in the Paraná Basin, possibly related to regional tectonic activity (Bosetti et al., 2012 and references therein). The studied sections by Bosetti et al. (2012) are late Emsian in age.

Some species recorded here are only known from Saudi Arabia or North Africa. These are Artemopyra inconspicua, Cymbosporites wellmanii, Devonomonoletes sp. 1 in Breuer and Steemans (2013), Dibolisporites sp. 2 and 3 in Breuer and Steemans (2013), Granulatisporites concavus, Verrucosisporites nafudensis, Verrucosisporites sp. 1 in Breuer and Steemans, 2013, Verrucosisporites stictus and Zonotriletes sp. 5 in Jardine and Yapaudjan (1968). Distaverrucosisporites steemansii (Rubinstein et al., 2018) is only known from Uruguay. Some other species have a pandemic distribution, since they were first reported in Saudi Arabia (Steemans, 1995; Breuer et al., 2007; Breuer and Steemans, 2013); these include Cymbohilates baqaensis, Cymbosporites dammamensis, Emphanisporites cf. laticostatus, Verrucosisporites onustus, Zonotriletes simplicissimus. These species were subsequently recorded in Uruguay (Rubinstein et al., 2018), Brazil (Grahn et al., 2010a), Argentina (Noetinger, 2015; Noetinger et al., 2018) and Spain (Cascales-Miñana et al., 2016). Thus, these data demonstrate the existence of a strong paleogeographical relationship between the South America, North Africa, Saudi Arabia and Spain. This is not surprising, as those localities belong to the Gondwanan and peri-Gondwana areas. Nevertheless, latitudinal differences are evident between North Africa-Saudi Arabia and Brazil (Boucot et al., 2013). The climate varies between these regions from cool temperate to cold, according to Boucot et al. (2013). The similitude of the vegetation would indicate that either the climates were not too different, which is supported by a moderate global climatic gradient interpreted for the Early Devonian (Boucot et al., 2013), or that the plants that produced those spores might have tolerated a large range of climates (García Muro et al., 2014). This spreading of the vegetation through the paleolatitudes has already been noted by Gerrienne et al. (2001).

\subsection{Geochemistry}

The stratigraphic framework observed in the Jaciara section (Fig. 4) is characteristic of a ramp basin type, as is most of the Paraná Basin. Lindsay et al. (1993) characterized this basin type by a slow subsidence rate, low depositional slopes and shallow water depths. These aspects produced a decrease in sediment accommodation within the basin, with extensive and thin sequences. In this basin physiography, the relative sea-level fall significantly affects the rate of regression on a gently sloping ramp. Consequently, the depositional and physiographic constraints of the ramp basin type enable the process of forced regression, increasing the influx of terrestrial material into the basin. This, in turn, makes possible the dilution of the TOC content and oxidation of the organic matter.

Commonly, high TOC values indicate transgressive marine conditions and are often associated with marine flooding surfaces (MFS), when the dysoxic/anoxic conditions further the preservation of organic matter (Pereira et al., 2007). The horizons with the highest TOC content in the Jaciara section fit very well with the shale intervals and can represent the progressive flooding events occurring in the Paraná Basin during the Early Devonian. Those events culminated in the third-order maximum flooding surface, proposed to be positioned near the Pragian/Emsian boundary by Bergamaschi and Pereira (2001) corresponding to the early Emsian according to the miospore biostratigraphy of the Jaciara section. In that section, the TOC values show an interesting relationship with the carbon organic isotopic ratio. For the Devonian interval of the Paraná Basin, Pereira et al. (2010a, 2010b) suggest the existence of an inverse relationship between the TOC content and the carbon isotopic values of the preserved organic matter ( $\delta^{13} \mathrm{Corg}$.). The authors demonstrated that the ranges with higher TOC content (more than $2 \%$ ) are associated with flooding surfaces with negative $\delta^{13}$ Corg values. Dias and Rodrigues (2006) advocated for more negative values 


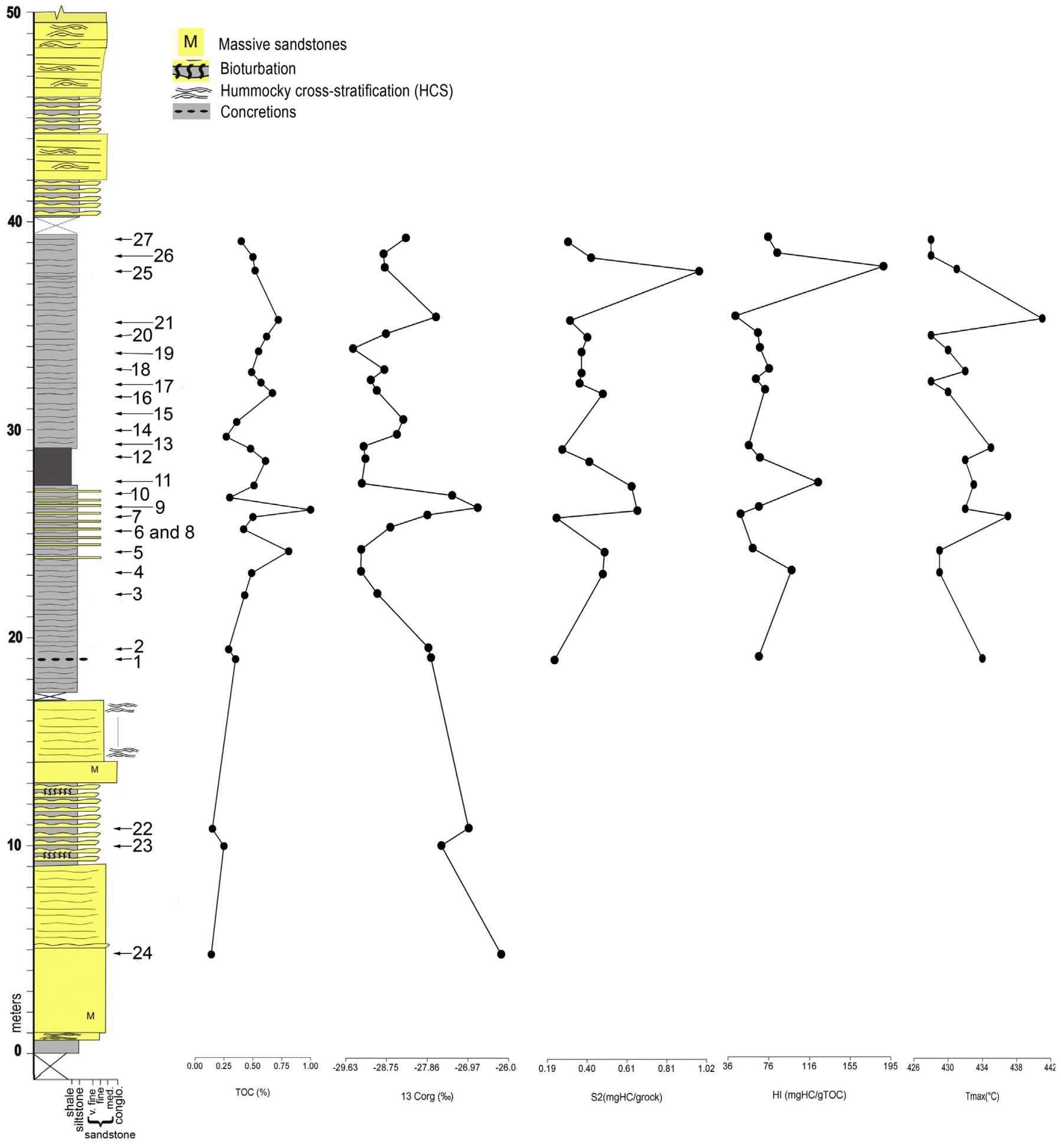

Fig. 4. Geochemistry and isotopic data from the Jaciara section.

$(-29 \%)$ of the carbon isotopes of the organic matter for the Lower Devonian of the Paraná Basin. According to these authors, based on biomarker analysis, this fact may be associated with the presence of lipidrich amorphous organic matter of a marine type. However, in the Jaciara section, the highest TOC levels occur where the isotope values $\left(\delta^{13} \mathrm{Corg}\right)$ are more positive (Fig. 4). The higher values of $\delta^{13}$ Corg in samples $(-27 \%$ o to $-26 \%$ ) from the lower part of the section seem to show a greater contribution from higher plants (Chen et al., 2017). The data for the samples at the middle part of the section (more negative, from $-29 \%$ to $-28 \%$ ) probably indicate a greater contribution from marine algae (Golyshev et al., 1991; Rodrigues et al., 1995). This matches with the more distal facies recorded in the section. The higher isotopic values might reflect the high influx of continental organic matter, although it is not represented by a major spore abundance. The introduction of terrestrial palynomorphs into the basin, together with the progradational sandstones, which are associated with lowstand wedge deltaic/upper shoreface deposits are linked to forced regressions, marked by the sandstones preserved in the section.

The modified van Krevelen diagrams use the oxygen versus hydrogen index (OI versus $\mathrm{HI}$ ) from Rock-Eval pyrolysis. The HI value below 


\begin{tabular}{|c|c|c|c|c|c|}
\hline & \multicolumn{5}{|c|}{ Devonian } \\
\hline & \multicolumn{3}{|c|}{ Lower } & \multicolumn{2}{|c|}{ Middle } \\
\hline & Lochko. & Pragian & Emsian & Eifelian & Givetian \\
\hline \multicolumn{6}{|l|}{ Ambitisporites eslae } \\
\hline \multicolumn{6}{|l|}{ Amicosporites streelii } \\
\hline \multicolumn{6}{|l|}{ Aneurospora isidori } \\
\hline \multicolumn{6}{|l|}{ Apiculiretusispora brandtii } \\
\hline \multicolumn{6}{|l|}{ Apiculiretusispora plicata } \\
\hline \multicolumn{6}{|l|}{ Artemopyra recticosta } \\
\hline \multicolumn{6}{|l|}{ Brochotriletes bellatulus } \\
\hline \multicolumn{6}{|l|}{ Brochotriletes foveolatus } \\
\hline \multicolumn{6}{|l|}{ Camarozonotriletes alruwailii } \\
\hline \multirow{2}{*}{\multicolumn{6}{|c|}{ Chelinospora retorrida }} \\
\hline \multirow{2}{*}{\multicolumn{6}{|c|}{ Chelinospora verrucata var. verrucata Morphon }} \\
\hline \multirow{2}{*}{\multicolumn{6}{|c|}{ Concentricosisporites agradabilis }} \\
\hline \multirow{2}{*}{\multicolumn{6}{|c|}{ Concentricosisporites sagittarius }} \\
\hline & & & & & \\
\hline \multicolumn{6}{|l|}{ Cymbohilates allenii var. magnus } \\
\hline \multicolumn{6}{|l|}{ Cymbohilates baqaensis } \\
\hline \multicolumn{6}{|l|}{ Cymbohilates horridus } \\
\hline Cymbosporites asymmetricus & & & & & \\
\hline Cymbosporites dammamensis & & & & & \\
\hline Cymbosporites dittonensis & & & & & \\
\hline Cymbosporites echinatus & & & & & \\
\hline Cymbosporites rarispinosus & & & & & \\
\hline Cymbosporites wellmanii & & & & & \\
\hline Devonomonoletes sp. 1 in Breuer and Steemans (2C & & & & & \\
\hline Dibolisporites wetteldorfensis & & & & & \\
\hline Dibolisporites echinaceus & & & & & \\
\hline Dibolisporites eifeliensis & & & & & \\
\hline Dibolisporites sp. 2 in Breuer and Steemans (2013) & & & & & \\
\hline Dibolisporites sp. 3 in Breuer and Steemans (2013) & & & & & \\
\hline Dictyotriletes emsiensis & & & & & \\
\hline Dictyotriletes subgranifer & & & & & \\
\hline Distaverrucosisporites steemansii & & & & & \\
\hline Emphanisporites laticostatus & & & & & \\
\hline Emphanisporites mcgregorii & & & & & \\
\hline Emphanisporites protophanus & & & & & \\
\hline Emphanisporites? tenuis & & & & & \\
\hline Granulatisporites concavus & & & & & \\
\hline Kraeuselisporites gaspesiensis & & & & & \\
\hline Latosporites ovalis & & & & ? & \\
\hline Perotriletes caperatus & & & & & \\
\hline Retusotriletes maculatus & & & & & \\
\hline Retusotriletes triangulatus & & & & & \\
\hline Scylaspora costulosa & & & & & \\
\hline Synorisporites papillensis Morphon & & & & & \\
\hline Synorisporites verrucatus & & & & & \\
\hline Verrucosisporites nafudensis & & & & & \\
\hline Verrucosisporites onustus & & & & & \\
\hline Verrucosisporites sp. 1 in Breuer and Steemans (20 & & & & & \\
\hline Verrucosisporites stictus & & & & & \\
\hline Zonotriletes brevivelatus & & & & & \\
\hline Zonotriletes simplicissimus & & & & & \\
\hline Zonotriletes sp. 5 in Jardiné and Yapaudjian (1968) & & & & & \\
\hline
\end{tabular}

Fig. 5. Global stratigraphic distribution of selected miospore species.

200 (mg HC/g COT) (Fig. 4) indicates organic matter with low thermal evolution and composed of organic matter Type II/III, but with a predominance of Type III, which are composed predominantly of phytoclasts (Peters et al., 2005).

\section{Conclusions}

The stratigraphic distribution of the miospores observed in the Jaciara section suggests a late Pragian to late-early Emsian age or 


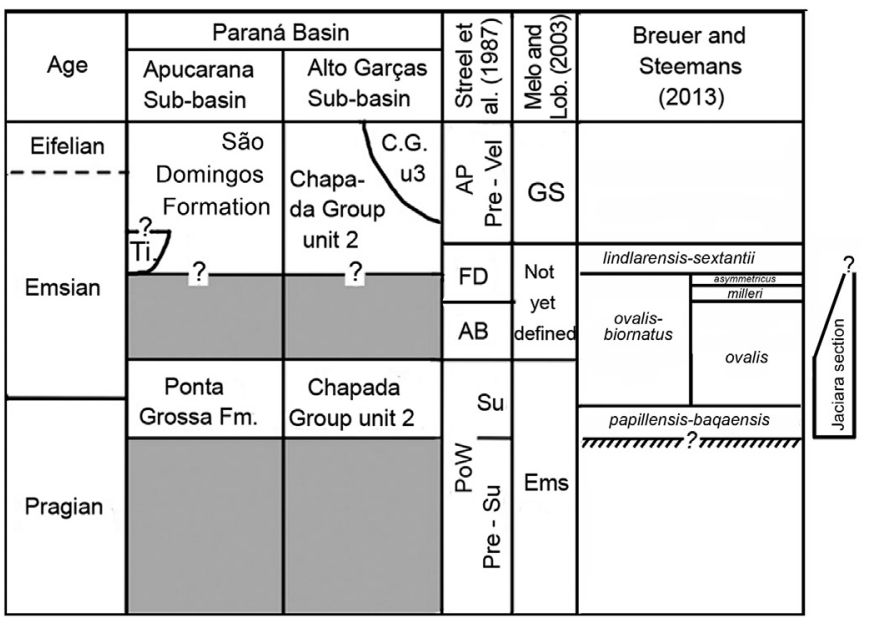

Fig. 6. Integrated correlation of standard Lower-Middle Devonian stages; lithostratigraphic scheme of the Paraná Basin (Grahn et al., 2013); Euramerica (Streel et al., 1987), Brazil (Melo and Loboziak, 2003) and northern part of Western Gondwana (Breuer and Steemans, 2013) miospore zonations and miospore data of the Jaciara section (this work). Modified from Grahn et al. (2013) and Breuer and Steemans (2013). Ti.: Tibagi Member of the São Domingos Formation; C.G. u3: Chapada Group unit 3; Lob.: Loboziak.

possibly middle Emsian. In the lower part, at samples 24-4, the miospore assemblage corresponds to the papillensis-baqaensis Biozone, dated as late Pragian. Above that part, in samples 5-21,the late-early Emsian asymmetricus Subzone of the ovalis-biornatus Biozone is recognised, equivalent to the upper part of the the Emsian $A B$ Biozone of Streel et al. (1987). Upwards, from sample 25 to 27 a middle Emsian age corresponding to the lindlarensis-sextantii Biozone cannot be discarded. Comparison with different biozones points to a better correlation with the biozonation established for the northern margin of western Gondwana (Saudi Arabia and North Africa), followed by that of Euramerica, and less accurately with the Brazilian biozones.

The presence of many taxa in common with other Gondwanan basins, particularly those from Saudi Arabia, North Africa and South America, corroborates the paleogeographical relationship between different regions of Gondwana, even between those located in very different paleolatitudes.

The organic matter of the Jaciara section is immature, with a low thermal evolution, and mainly corresponds to kerogen Type III.

The depositional setting and the physiographic constraints of the ramp-type basin favor the process of forced regression, which increases terrestrial material influx into the basin and leads to dilution of the TOC content and oxidation of the organic matter. In the Jaciara section, the geochemistry and isotope data demonstrate a strong influence of the basin physiography on the Devonian depositional setting. The residual TOC content is diluted, exhibiting values below $1 \%$. The mixed organic matter (marine and continental), defined by the positive excursion of $\delta 13$ Corg ( $-29 \%$ o to $-26 \%$ ), and the spore diversity, recorded in the Jaciara section, are responses to the high sedimentary influx associated with the forced regression episodes during the Early Devonian transgression.

\section{Author Contributions}

Field work, collection of samples, sedimentological and geochemical analysis, interpretation of data and writing: Egberto Pereira and Sergio Bergamascchi.

Palynological investigation, interpretation of data and writing: Victoria J. García Muro, Claudia V. Rubinstein and Philippe Steemans.

First palynological investigation: Paula Mendlowicz Mauller.

Visualization: Egberto Pereira and Victoria J. García Muro.

\section{Declaration of Competing Interest}

We have no conflict of interest.

\section{Acknowledgements}

We thank Marcela Giraldo (Université de Liège, Belgium) for the palynological laboratory processing. Financial support for Victoria J. García Muro and Claudia V. Rubinstein was provided by FONCYT (PICT 20150473 and PICT 2017-0532). Egberto Pereira and Sérgio Bergamaschi thank CNPq and FAPERJ to support the Chemo stratigraphy and Organic Geochemistry Laboratory (LGQM). Philippe Steemans is a FSR-NFSR, Belgium Senior Researcher. We acknowledge to the reviewers P. Filipiak and P. Breuer for their useful comments to improve the manuscript.

\section{Appendix A. Appendix}

Acinosporites sp. 1 (Plate I, 1)

Description: Trilete spore with subtriangular amb. Trilete mark distinct, straight, extending $2 / 3$ of the spore radius. Ornaments consist of anastomosing ridges and verrucae in plan view, of $0.5 \mu \mathrm{m}$ high. Furrows between the ridges are 1-2 $\mu \mathrm{m}$ wide.

Dimensions: $36 \mu \mathrm{m}$ (one specimen measured)

Occurrence: Sample 5, sample 61836 (Q44)

Comparison: This specimen differs from other species in presenting shorter-closely distributed to mostly fused ornaments, with very short spinose projection. A. apiculatus has higher ornaments and wider amb.

Ambitisporites eslae (Cramer and Díez) Richardson et al., 2001 (Plate I, 2, 16)

Ambitisporites sp. 1 (Plate I, 18-20)

Description: Trilete spore with subtriangular amb. Exine distally and equatorially thickened, that seems to be irregular in the equator. Thickened of 4-7 $\mu \mathrm{m}$ wide in the equatorial area. Proximal face presents a subcircular papilla in each interradial zone of 3-6 $\mu \mathrm{m}$ wide. Leasurea extends up to the inner margin of the patina, sometimes accompanied by thick labra of $1-2 \mu \mathrm{m}$ in combined width.

Dimensions: $32-40 \mu \mathrm{m}$ (three specimens measured)

Occurrence: Sample 1, sample 61654 (Q39-2); sample 4, sample 61660 (H37/1); sample 19, sample 61690 (M48).

Comparison: Ambitisporites eslae does not present labra.

Ambitisporites sp. (Plate I, 3)

Amicosporites streelii Steemans, 1989 (Plate I, 4)

Aneurospora isidori (Cramer and Díez) Richardson et al., 1982 (Plate I, 5)

Aneurospora sp. 1 in Rubinstein and Steemans (2002) (Plate I, 6)

Aneurospora sp. 2 in Rubinstein and Steemans (2002) (Plate I, 7)

Aneurospora cf. sp. 4 in Rubinstein and Steemans (2002) (Plate I, 8)

Aneurospora sp. 5 in Rubinstein and Steemans (2002) (Plate I, 9-10)

Apiculiretusispora brandtii Streel, 1964 (Plate I, 11-12)

Apiculiretusispora plicata (Allen) Streel, 1967 (Plate I, 13-14)

Archaeozonotriletes chulus (Cramer) Richardson and Lister, 1969 (Plate I, 15)

Archaeozonotrilets sp. 1 (Plate I, 17)

Description: Trilete spore with subtriangular amb. Exine equatorially and distally thickened. The very thick distal patina seems to be irregular. Proximal face presents one inspissation in each interradial contact area of 3-6 $\mu \mathrm{m}$ wide. Leasurae extend up to the equatorial margin.

Dimensions: $37 \mu \mathrm{m}$ (one specimen measured)

Occurrence: Sample 2, sample 61833 (L51)

Comparison: Archaeozonotriletes variabilis presents laevigate interradial zones. Ambitisporites eslae has interradial papillae, not inspissations, and is not patinated.

Remarks: Although very different, the only registered specimen does not allow the establishment of a new species.

Artemopyra recticosta Breuer et al., 2007 (Plate II, 1-2)

Brochotriletes bellatulus Steemans, 1989 (Plate II, 3) 
Brochotriletes foveolatus Naumova, 1953 (Plate II, 4)

Camarozonotriletes alruwailii Breuer et al., 2015 (Plate II, 5)

Chelinospora retorrida Turnau, 1986 (Plate II, 6)

Chelinospora verrucata var. verrucata Morphon García Muro et al.

(2014) (Plate II, 7)

Concentricosisporites agradabilis (Rodriguez) Rodriguez, 1983

(Plate II, 8)

Concentricosisporites cf. C. sagittarius (Rodriguez) Rodriguez, 1983

(Plate II, 9)

Cymbohilates allenii var. magnus Richardson, 1996 (Plate II, 11)

Cymbohilates baqaensis Breuer et al., 2007 (Plate II, 12)

Cymbohilates horridus Richardson, 1996 (Plate II, 13)

Cymbohilates sp. (Plate II, 14)

Cymbosporites asymmetricus Breuer et al., 2007 (Plate II, 15)

Cymbosporites dammamensis Steemans, 1995 (Plate II, 16)

Cymbosporites dittonensis Richardson and Lister, 1969 (Plate II, 17)

Cymbosporites echinatus Richardson and Lister, 1969 (Plate II, 18)

Cymbosporites rarispinosus Steemans, 1989 (Plate II, 19)

Cymbosporites wellmanii Breuer and Steemans, 2013 (Plate II, 20)

Devonomonoletes sp. 1 in Breuer and Steemans (2013) (Plate III, 2)

cf. Devonomonoletes sp. 1 in Breuer and Steemans (2013) (Plate III, 1)

10)

Dibolisporites echinaceus (Eisenack) Richardson, 1965 (Plate III, 3

Dibolisporites eifeliensis (Lanninger) McGregor, 1973 (Plate III, 4, 9)

Dibolisporites cf. D. wetteldorfensis Lanninger, 1968 (Plate III, 5)

Dibolisporites sp. 1 (Plate III, 6)

Description: Trilete spore with subtriangular amb, with an equatorial

thickening of $4 \mu \mathrm{m}$ wide. Trilete mark nearly equal to spore radius,

laesurae simple. Contact areas smooth.

Exine outside contact areas bear a biform sculpture of tapering conical ornaments surmounted by expanded tip elements of $2 \mu \mathrm{m}$ high, 1-4 $\mu \mathrm{m}$ apart.

Dimensions: $45 \mu \mathrm{m}$ (one specimen measured)

Occurrence: Sample 23, sample 61854 (S35-3)

Comparison: This specimen is similar to Dibolisporites bullatus

(Allen) Riegel, 1973 in size and distance among ornaments, but they are not spinae-like. It does not present dark labra either. D. tuberculatus Breuer and Steemans (2013) is similar but it has in general higher ornaments and a circular to sub-circular amb.

Dibolisporites sp. 2 in Breuer and Steemans (2013) (Plate III, 7-8)

Dictyotriletes emsiensis Morphon Rubinstein et al. (2005)

(Plate III, 11)

Dictyotriletes subgranifer McGregor, 1973 (Plate III, 12)

Distaverrucosisporites steemansii Rubinstein et al., 2018 (Plate III, 13)

Emphanisporites cf. E. laticostatus Breuer and Steemans, 2013

(Plate III, 14)

Emphanisporites mcgregorii Cramer, 1966 (Plate III, 15)

Emphanisporites neglectus Vigran, 1964 (Plate III, 16)

Emphanisporites protophanus Richardson and Ioannides, 1973 (Plate

III, 17)

Emphanisporites rotatus (McGregor) McGregor 1973 (Plate III, 18)

Emphanisporites? tenuis García Muro et al., 2018 (Plate III, 19-20)

Gneudnaspora divellomedia (Chibrikova) Balme, 1988 var.

divellomedia Breuer et al., 2007 (Plate IV, 1)

Granulatisporites concavus Breuer and Steemans, 2013 (Plate IV, 2)

Kraeuselisporites gaspesiensis McGregor, 1973 (Plate IV, 3)

Latosporites ovalis Breuer et al., 2007 (Plate IV, 4)

cf. Latosporites sp. (Plate IV, 5)

Perotrilites caperatus (McGregor) Steemans, 1989 (Plate V, 4)

Retusotriletes maculatus McGregor and Camfield, 1976 (Plate IV, 7)

Retusotriletes triangulatus (Streel) Streel, 1967 (Plate IV, 8)

Retusotriletes spp. (Plate IV, 6, 9)

Scylaspora costulosa Breuer et al., 2007 (Plate IV, 10-11)

Scylaspora sp. 1 (Plate IV, 12-13)

Description: Trilete spore with equatorial thickened, up to $1.4 \mu \mathrm{m}$

wide. Trilete mark equal to spore radius, laesurae simple. Proximal face ornamented with thin and low convolute muri. Distal face presents one papillae of $4 \mu \mathrm{m}$ wide in coincidence with the interradial zones.

Dimensions: $33 \mu \mathrm{m}$ (two specimens measured)

Occurrence: Sample 15, sample 61846 (N36-1); sample 26, sample 61704 (G45)

Comparison: Scylaspora elegans presents a darker area bordering the trilete mark.

Synorisporites papillensis Morphon Breuer and Steemans, 2013

(Plate IV, 14)

Synorisporites verrucatus Richardson and Lister, 1969 (Plate IV, 15)

Tetrahedraletes medinensis (Strother and Traverse) Wellman and

Richardson, 1993 (Plate IV, 16)

Verrucosisporites nafudensis Breuer and Steemans, 2013

(Plate IV, 17)

Verrucosisporites onustus Breuer and Steemans, 2013 (Plate IV, 18)

Verrucosisporites stictus Breuer and Steemans, 2013 (Plate IV, 19)

Verrucosisporites sp. 1 in Breuer and Steemans (2013) (Plate IV, 20)

Zonotriletes brevivelatus Breuer and Steemans, 2013 (Plate V, 1)

Zonotriletes cf. simplicissimus Breuer et al., 2007 (Plate II, 10; V, 2)

Remark: The observed specimens in the Jaciara section are smaller

than Zonotriletes simplicissimus Breuer et al., 2007.

Zonotriletes sp. 5 in Jardiné and Yapaudjian (1968) (Plate V, 3)

\section{References}

Andrade, S.M., Camarço, P.E.N., 1980. Estratigrafia dos sedimentos devonianos do flanco nordeste da bacia do Paraná. 31st Congresso Brasileiro de Geologia. Camboriú, Brazil, pp. 2828-2836.

Andrade S.M. Camarço, P.E.N 1982. Seqüências sedimentares précarboníferas dos flancos nordeste da bacia do Paraná e sudoeste da bacia Do Parnaíba e suas possibilidades uraníferas. 32nd Congresso Brasileiro de Geologia. Salvador, Brazil, pp. 2132-2144.

Bergamaschi, S., Pereira, E., 2001. Caracterização de Sequências Deposicionais de 3ao ordem para o Siluriano-Devoniano na Sub-bacia de Apucarana, Bacia do Paraná, Brasil. In: Melo, J.H.G., Terra, G.J.S. (Eds.), Correlação de Sequências Paleozóicas SulAmericanas. vol. 20, pp. 63-73 Ciência-Técnica-Petróleo, Seção Exploração de Petróleo.

Bosetti, E.P., Grahn, Y., Horodyski, R.S., Mauller, P.M., 2012. The first recorded decline of the Malvinokaffric Devonian fauna in the Paraná Basin (southern Brazil) and its cause; taphonomic and fossil evidences. J. S. Am. Earth Sci. 37, 228-241.

Boucot, A.J., Xu, C., Scotese, C.R., Morley, R.J., 2013. Phanerozoic paleoclimate: An atlas of lithologic indicators of climate. In: Nichols, G.J., Ricketts, B. (Eds.), SEPM Concepts in Sedimentology and Paleontology No. 11: Map Folio. SEPM (Society for Sedimentary Geology), Tulsa, OK, pp. 1-30.

Breuer, P., Steemans, P., 2013. Devonian miospores from northwestern Gondwana. Spec. Pap. Palaeontol. 89, 1-163.

Breuer, P., Al-Ghazi, A., Al-Ruwaili, M., Higgs, K.T., Steemans, P., Wellman, C.H., 2007. Early to middle Devonian miospores from northern Saudi Arabia. Rev. Micropaleontol. 50 (1), 27-57.

Breuer, P. Miller, M.A., Leszczyński, S., Steemans, P., 2015. Climate-controlled palynofacies and miospore stratigraphy of the Jauf Formation, Lower Devonian, northern Saudi Arabia. Rev. Palaeobot. Palynol. 212, 187-213.

Cascales-Miñana, B, Gerrienne, P. Moreno-Domínguez, R., Xue, J. Valenzuela-Ríos, J.I. Diez, J.B., Rial, G., Steemans, P., 2016. A new highly diverse palynoflora from the Lower Devonian Nogueras Formation of the Iberian Peninsula. Hist. Biol. 28 (8), 1118-1124.

Chen, J., Deng, C., Wang, H., Sun, X., 2017. Main oil generating macerals for coal-derived oil: A case study from the Jurassic coal-bearing Turpan Basin, NW China. Org. Geochem. 111, 113-125.

Cramer, F.H., Diéz, M. del C., 1975. Earliest Devonian miospores from the province of Leon, Spain. Mus. Natl. D'Hist. Nat. 17, 331-344.

Dias, A.E.S., Rodrigues, R., 2006. Chemostratigraphic assessment (total organic carbon, carbon) stable isotopes, pyrolysis and biomarkers of lower devonian interval of the Paraná Basin, Brazil. 10th Alago Congress on Organic Geochemistry, Salvador, pp. 347-349 extended abstract.

Dino, R., Rodrigues, M.A.C., 1995. Palinomorfos eodevonianos da Formação Furnas, bacia do Paraná. An. Acad. Bras. Cienc. 67, 107-116.

Dorning, K.J., Bell, D.G., 1987. The Si lu rian car bon ate shelf microflora: acritarch dis tri bu tion in the Much Wen lock Lime stone. In: Hart, M. (Ed.), Micropalaeontology of Carbonate Environments. Ellis Horwood, Chichester, pp. 266-287.

Espitalié, J., Laporte, J.L., Madec, M., Marquis, F., Leplat, P., Paulet, J., 1977. Méthod rapide de caractérization des roches mères, de leur potentiel pétrolier et de leur degré d'évolution. Rev. l' Inst. Fran. Pétrol. 32, 23-43.

Evans, J.W., 1894. The geology of Matto Grosso (particularly the region drained by the Upper Paraguay). Q. J. Geol. Soc. 50, 85-104

García Muro, V.J., Rubinstein, C.V., Steemans, P., 2014. Upper Silurian miospores from the Precordillera Basin, Argentina: Biostratigraphic, palaeonvironmental and palaeogeographic implications. Geol. Mag. 151 (3), 472-490. 
Gerrienne, P., Bergamaschi, S., Pereira, E., Rodrigues, M.A.C., Steemans, P., 2001. An Early Devonian flora, including Cooksonia, from the Paraná Basin (Brazil). Rev. Palaeobot. Palynol. 116 (1-2), 19-38.

Golyshev, S.I., Verkhovskaya, N.A., Burkova, V.N., Matis, E.Y., 1991. Stable carbon isotopes in source-bed organic matter of West and East Siberia. Org. Geochem. 17, 277-291.

Grahn, Y., Pereira, E., Bergamaschi, S., 2000. Silurian and Lower Devonian chitinozoan biostratigraphy of the Paraná Basin in Brazil and Paraguay. Palynology 24, 143-172.

Grahn, Y., Melo, J.H.G., Steemans, P., 2005. Integrated chitinozoan and miospore zonation of the Serra Grande Group (Silurianlower Devonian), Parnaíba Basin, northeast Brazil. Rev. Esp. Micropaleontol. 37, 183-204.

Grahn, Y., Mendlowicz Mauller, P., Pereira, E., Loboziak, S., 2010a. Palynostratigraphy of the Chapada Group and its significance in the Devonian stratigraphy of the Paraná Basin, south Brazil. J. S. Am. Earth Sci. 29, 354-370.

Grahn, Y., Mendlowicz Mauller, P., Breuer, P., Bosetti, E.P., Bergamaschi, S., Pereira, E., 2010b. The Furnas/Ponta Grossa contact and the age of the lowermost Ponta Grossa Formation in the Apucarana sub-basin (Parana Basin, Brazil): integrated palynological age determination. Rev. Brasil. Paleontol. 13, 89-102.

Grahn, Y., Mendlowicz Mauller, P., Bergamaschi, S., Bosetti, E.P., 2013. Palynology and sequence stratigraphy of three Devonian rock units in the Apucarana Subbasin (Paraná Basin, south Brazil): additional data and correlation. Rev. Palaeobot. Palynol. 198, 27-44.

Guerra-Sommer, M., Cazzulo-Klepzig, M., Formoso, M.L.L., Menegat, R., Fo, J.G.M., 2008. $\mathrm{U}-\mathrm{Pb}$ dating of tonstein layers from a coal succession of the southern Paraná Basin (Brazil): A new geochronological approach. Gondwana Res. 14 (3), 474-482.

Higgs, K.T., Williams, P.J., 2011. Palynology and palaeoenvironments of the Silurian Coosglass Slate and Ferriter's Cove formations in the Dunquin Inlier (Dingle Peninsula, Ireland). Geol. Quart. 55 (2), 95-108.

Holz, M., França, A.B., Souza, P.A., Iannuzzi, R., Rohn, R., 2010. A stratigraphic chart of the Late Carboniferous/Permian succession of the eastern border of the Paraná Basin, Brazil, South America. J. S. Am. Earth Sci. 29 (2), 381-399.

Jardine, S., Yapaudjan, L., 1968. Lithostratigraphie et palynologie du DévonienGothiandien gréseux du Bassin de Polignac (Sahara). Rev. l'Inst. Fran. Pétrol. 23 (4), 439-468.

Lindsay, J.F., Kennard, J.M., Southgate, P.N., 1993. Application of sequence stratigraphy in an intracratonic setting, Amadeus Basin, central Australia. In: Posamentier, H.W., Summerhayes, C.P., Haq, B.U., Allen, G.P. (Eds.), Sequence Stratigraphy and Facies Associations. 18. International Association of Sedimentologists, pp. 605-631 Special Publication.

Liu, F., Kerp, H., Peng, H., Zhu, H., Peng, J., 2019. Palynostratigraphy of the DevonianCarboniferous transition in the Tulong section in South Tibet: A Hangenberg Event sequence analogue in the Himalaya-Tethys zone. Palaeogeogr. Palaeoclimatol. Palaeoecol. 531, 108704.

Melo, J.H.G., 1988. The Malvinokaffric realm in the Devonian of Brazil. In: McMillan, N.J., Embry, A.F., Glass, D.J. (Eds.), Devonian of the World: Proceedings of the 2nd International Symposium on the Devonian System: Regional Syntheses. 1, pp. 669-703 No. 14.

Melo, J.H.G., Loboziak, S., 2003. Devonian-Early Carboniferous miospore biostratigraphy of the Amazon Basin, northern Brazil. Rev. Palaeobot. Palynol. 124, 131-202.

Mendlowicz Mauller, P., Machado Cardoso, T.R., Pereira, E., Steemans, P., 2007. Palynostratigraphic results on the Devonian of the Alto Garças Sub-basin (Paraná Basin - Brazil). In: Souza Carvalho, I., et al. (Eds.), Paleontologia: Cenários de Vida 2. Editoria Interciência Ltda, Rio de Janeiro, pp. 607-619.

Mendlowicz Mauller, P., Grahn, Y., Machado Cardoso, T.R., 2009. Palynostratigraphy from the Lower Devonian of the Paraná Basin, South Brazil, and a revision of contemporary Chitinozoan biozones from Western Gondwana. Stratigraphy 6 (4), 313-332.

Milani, E.J., Faccini, U.F., Scherer, C.M.S., Araújo, L.M., Cupertino, J.A., 1998. Sequences and stratigraphic hierarchy of the Paraná Basin (Ordovician to Cretaceous), Southern Brazil. Boletim IG-USP. 29. Série Científica, São Paulo, pp. 125-173.

Milani, E.J., França, A.B., Medeiros, R.A., 2006. Rochas geradoras e rochas-reservatório da Bacia do Paraná, faixa oriental de afloramentos, estado do Paraná. Bol. Geoci. Petrob. 15 (1), 135-162.

Milani, E.J., Melo, J.H.G., Souza, P.A., Fernandes, L.A., França, A.B., 2007. Bacia do Paraná. Bol. Geoci. Petrob. 15 (2), 265-287.

Molyneux, S.G., Le Hérissé, A., Wicander, R., 1996. Palaeozoic phytoplankton. In: Jansonius, J., McGregor, D.C. (Eds.), Palynology: Principles and Applications. 2. American Association of Stratigraphic Palyhologists Foundation, pp. 193-529.
Noetinger, S., 2015. Spore diversity trends in the Middle Devonian of the Chaco-Salteño Plain, northwestern Argentina. Palaeogeogr. Palaeoclimatol. Palaeoecol. 417, 151-163.

Noetinger, S., di Pasquo, M., Starck, D., 2018. Middle-Upper Devonian palynofloras from Argentina, systematic and correlation. Rev. Palaeobot. Palynol. 257, 95-116.

Pereira, E., Bergamaschi, S., Rodrigues, M.A., 1998. Sedimentary evolution of the Ordovician, Silurian and Devonian sequences of Paraná Basin in Brazil. Zentralblatt für Geologie und Paläontologie Teil 1, 779-792.

Pereira, E., Aguiar, A.P.O., Brasil, F.A.F., Blazutti, D., 2007. Estratigrafia de Alta Resolução e o registro icnofaciológico. In: Souza Carvalho, I., Siqueira Fernandes, A.C. (Eds.), Icnologia. Sociedade Brasileira de Geologia, pp. 32-39.

Pereira, E., Rodrigues, R., Bergamaschi, S., Souza, M.S.P., 2010a. Caracterização Químioestratigráfica do Devoniano Inferior da Bacia do Paraná. X Congresso de Geoquímica dos Países de Língua Portuguesa, Porto - Portugal, pp. 349-353.

Pereira, E., Rodrigues, R., Bergamaschi, S., Souza, M.S.P., 2010b. $\delta^{13} C_{\text {organic }}$ characterization of Late Devonian flooding surfaces in the Paraná Basin. Proceedings of VII SSAGI South American Symposium on Isotope Geology, Brasília, pp. 544-547.

Pereira, E., Carneiro, C.R., Bergamaschi, S., Almeida, F.F.M., 2012. Evolução das Sinéclises Paleozoicas: Províncias Solimões, Amazonas, Parnaíba e Paraná. . (Org.). In: Hasui, Yociteru, Carneiro, Celso Del Ré, de Almeida, Fernando Flávio, Bartoreli, Andréa (Eds.), Geologia do Brasil, 1 ed vol. 1. Beca-BALL Edições Ltda, São Paulo, pp. 374-394 2012, v.

Peters, K.E., Walters, C.C., Moldowan, J.M., 2005. The Biomarker Guide. Vol. 1. Cambridge University Press, Cambridge, United Kingdom, p. 471.

Piccirillo, E.M., Melfi, A.J., Comin-Chiaramonti, P., Bellieni, G., Ernesto, M., Marques, L.S.M., Nardy, A.J.R., Pacca, I.G., Roisenberg, A., Stolfa, D., 1988. Continental flood volcanism from the Paraná Basin (Brazil). In: Macdougall, I.D. (Ed.), Continental Flood Basalts. Kluwer Academic Publishers, Springer, Dordrecht, pp. 195-238.

Posamentier, H.W. James, D.P. 1993. An overview of sequence-stratigraphic concepts: uses and abuses. Sequence Stratigraphy and Facies Associations. Special Publication 18. International Association of Sedimentology, pp. 3-18.

Ramos, A.N., 1970. Aspectos páleo-estruturais da Bacia do Paraná e sua influência na sedimentação. Bol. Técn. Petrob. 13, 85-93 Rio de Janeiro, Brazil.

Rodrigues, R., Loboziak, S., Melo, J.H.G., Alves, D.B., 1995. Geochemical characterization and miospore biochronostratigraphy of the Frasnian anoxic event in the Parnaíba Basin, northeast Brazil. Bull. Cent. Rech. Explor. Prod. Aquit. 19, 319-327.

Rodriguez, R.M., 1978. Mioesporas de la Formación San Pedro/Furada (Silúrico superiorDevónico Inferior), Cordillera Cantábrica, NO de España. Palinologia 1, 407-433.

Rubinstein, C.V., Melo, J.H.G., Steemans, P., 2005. Lochkovian (earliest Devonian) miospores from the Solimões Basin, northwestern Brazil. Rev. Palaeobot. Palynol. $133(1-2), 91-113$

Rubinstein, C.V., Lovecchio, J.P., Gebhard, I., 2018. Early Devonian marine and terrestria palynomorphs from the Chacoparaná Basin, Uruguay. Ameghiniana 55, 277-302.

Sedorko, D., Bosetti, E.P., Ghilardi, R.P., Myszynski Júnior, L.J., Silva, R.C., Scheffler, S.M., 2018. Paleoenvironments of a regressive Devonian section from Paraná Basin (Mato Grosso do Sul state) by integration of ichnologic, taphonomic and sedimentologic analyses. Braz. J. Geol. 48 (4), 805-820.

Souza, P.A., Marques Toigo, M., 2014. An overview on the palynostratigraphy of the Upper Paleozoic strata of the Brazilian Paraná Basin. Rev. Mus. Argent. Cien. Nat. nuev. ser. 5 (2), 205-214.

Steemans, P., 1989. Paléogéographie de l'Eodevonien ardennais et des regions limitrophes. Ann. Soc. Geol. Belg. 112 (1), 103-119.

Steemans, P., 1995. Silurian and lower Emsian spores in Saudi Arabia. Rev. Palaeobot. Palynol. 89 (1-2), 91-104.

Steemans, P., Rubinstein, C.V., Melo, J.H.G., 2008. Siluro-Devonian miospore biostratigraphy of the Urubu River area, western Amazon Basin, northern Brazil. Geobios 41 263-282.

Streel, M., Loboziak, S., Riegel, W., Steemans, P., 1987. Spore stratigraphy and correlation with faunas and floras in the type marine Devonian of the Ardenno-Rhenish regions. Rev. Palaeobot. Palynol. 50, 211-229.

Streel, M., Loboziak, S., Steemans, P., Bultynck, P., 2000. Devonian miospore stratigraphy and correlation with the global stratotype sections and points. In: Bultynck, P. (Ed.) Subcommission on Devonian Stratigraphy. Fossil groups important for boundary definition. Courier Forschungsinstitut Senckenberg, Frankfurt, pp. 9-23.

Traverse, A., 2007. Paleopalynology. Second ed. Springer, Dordrecht, p. 813.

Van Wagoner, J.C., Mitchum, R.M., Campion, K.M., Rahmanian, V.D., 1990. Siliciclastic sequence stratigraphy in well logs, cores, and outcrops. American Association of Petroleum Geologists. Method. Explor. Ser. 7, 55. 